Maurer School of Law: Indiana University

Digital Repository@Maurer Law

Indiana Law Journal

Volume 85 | Issue 3

Article 4

Summer 2010

\title{
Marital Naming/Naming Marriage: Language and Status in Family Law
}

Suzanne A. Kim

Rutgers School of Law-Newark, skim@kinoy.rutgers.edu

Follow this and additional works at: https://www.repository.law.indiana.edu/ilj

Part of the Family Law Commons

\section{Recommended Citation}

Kim, Suzanne A. (2010) "Marital Naming/Naming Marriage: Language and Status in Family Law," Indiana Law Journal: Vol. 85 : Iss. 3 , Article 4.

Available at: https://www.repository.law.indiana.edu/ilj/vol85/iss3/4

This Article is brought to you for free and open access by the Law School Journals at Digital Repository @ Maurer Law. It has been accepted for inclusion in Indiana Law Journal by an authorized editor of Digital Repository @ Maurer Law. For more information, please contact rvaughan@indiana.edu.

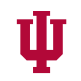

JEROME HALL LAW LIBRARY

INDIANA UNIVERSITY

Maurer School of Law
Bloomington 


\title{
Marital Naming/Naming Marriage: Language and Status in Family Law
}

\author{
SUZANNE A. KM*
}

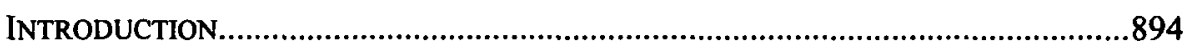

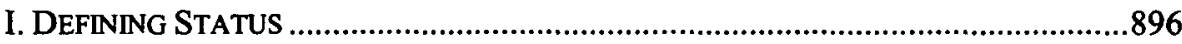

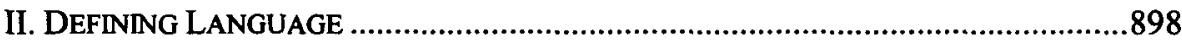

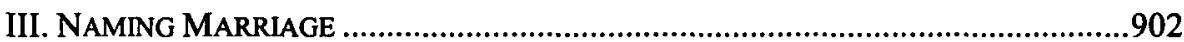

A. THE LANGUAgE OF SAME-SEX MARRIAGE........................................902

B. ThE PUBlic NATURE OF NAMING MARRIAGE ......................................904

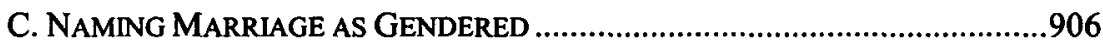

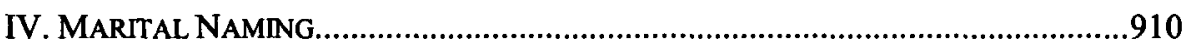

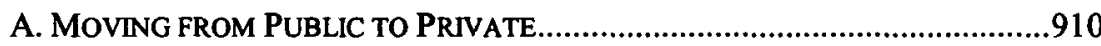

B. The Private Choice of MARTtaL NAMING ......................................922

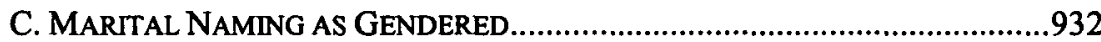

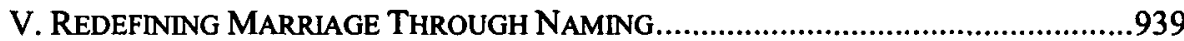

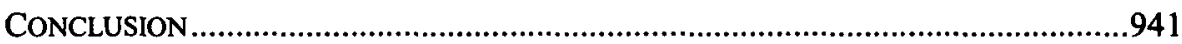

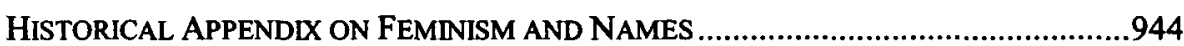

A. NAMES AND FEMINISM'S FIRST WAVE ...........................................944

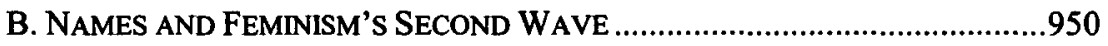

What's in a name? Based on current family law and policy debates, the answer would seem to be: a whole lot. Today's discussion of legal prohibitions of same-sex marriage abounds with the assumption that language, in the form of names and labels, is deeply meaningful from a status perspective. Missing from this debate, however, is a careful examination of the role that names and labels play in the construction of the status category of marriage. This Article fills this gap in family law scholarship by providing an explicit account of how language plays a critical role in reflecting and reinforcing gender hierarchy within the status category of marriage. This Article does so by considering the question of "naming marriage" in the same-sex marriage debate, whether same-sex couples otherwise entitled to the benefits of marriage are and should be entitled to the term "marriage," alongside the persistently gendered practices of "marital naming," by which women almost universally adopt their

* Associate Professor of Law, Rutgers School of Law-Newark. For comments on early drafts and for discussion of the ideas in this Article, I thank my colleagues at Rutgers, including Paul Axel-Lute, Carlos Ball, Vera Bergelson, Joshua Blank, Stuart Deutsch, Carlos Gonzalez, Stuart Green, Adil Haque, Alan Hyde, Howard Latin, Brandon Paradise, Twila Perry, Jim Pope, Sabrina Safrin, Paul Tractenberg, Mark Weiner; the Emerging Family Law Scholars Workshop of Greater New York, including Sarah Abramowicz, Holning Lau, Solangel Maldonado, Ed Stein, and Richard Storrow; the 2008 Northeast People of Color Legal Scholarship Conference participants, including Fabio Arcila, Elaine Chiu, and Adele Morrison; and Kerry Abrams, Richard Chused, Elizabeth Emens, Joanna Grossman, Maya Manian, Serena Mayeri, Catherine Piché, Marc Poirier, and Laura Rosenbury. The work for this Article was supported in part by the Dean's Research Fund of Rutgers School of Law-Newark. Many thanks to Matthew Coleman, Jessica Goldberg, Noelle Petruzelli-Marino, and Joyce Song for excellent research assistance; any errors are my own. I can be contacted at skim@kinoy.rutgers.edu. 
husbands' last names upon marriage, despite the formal freedom of women to retain their names and of men to adopt their wives' last names. This Article explores how the question of "naming marriage" concerns the outer, gendered boundaries of marriage, while "marital naming" constructs the category of marriage as internally gendered. Traditional naming practices work together to define marriage as gender hierarchical. This Article ultimately considers the potential for these two forms of naming to facilitate the transformation of marriage into a less gendered institution.

\section{INTRODUCTION}

Major debates in family law today proceed from the assumption that what we call relationships and the people in those relationships matters. Today's discussion of legal prohibitions of same-sex marriage rests on the belief that language, in the form of names and labels, is deeply meaningful from a status perspective. The current same-sex marriage debate reflects an assumption that language is inherently meaningful, capable of drawing lines of inclusion and exclusion and marking patterns of equality and injustice.

Missing from this debate, however, is a careful examination of the role that names and labels play in the construction of the status category of marriage. This Article fills this gap in family law scholarship by providing an explicit account of how language plays a critical role in reflecting and reinforcing gender hierarchy within status categories like marriage.

Family law abounds with examples of language affecting status, with shifts in language from "alimony" to "spousal support," "bastard" to "illegitimate child" to "child," and "unwed" to "cohabiting"" reflecting transformations in views on marriage, divorce, parenthood, and family.

1. Twila L. Perry, No-Fault Divorce and Liability Without Fault: Can Family Law Learn from Torts?, 52 Oніо ST. L.J. 55, 59 n.22 (1991) ("In recent years, there has been some movement away from the term 'alimony.' Alternative terms have included 'spousal support,' 'maintenance,' and 'spousal maintenance.' It has been argued that such terms more accurately reflect the idea of gender-neutral and fault-neutral claims based on need. To some, the term alimony may have negative connotations - most people have heard of the term 'alimony drone' and are well aware of the negative stereotype it invokes.").

2. The removal of barriers to full legal status for children of unmarried couples reveals a struggle over terms. Cases on illegitimacy focused on whether children of the unmarried should be treated as "children" for purposes of legal benefits and protections. See Weber v. Aetna Cas. \& Sur. Co., 406 U.S. 164, 165-67 (1972) (finding unconstitutional a Louisiana statute relegating unacknowledged illegitimate children to the status of "other dependents" for the purpose of receiving workmen's compensation benefits); Levy v. Louisiana, 391 U.S. 68, 70-72 (1968) (rejecting lower court's holding that illegitimate children were not included under Louisiana statute granting children right to recover for wrongful death of parent); De Sylva v. Ballentine, 351 U.S. 570, 580-82 (1956) (determining that illegitimate children were included in the phrase "children of the author" under the federal Copyright Act).

3. See Pamela J. Smock \& Wendy D. Manning, Living Together Unmarried in the United States: Demographic Perspectives and Implications for Family Policy, 26 LAW \& POL'Y 87 (2004). 
This Article explicates the role of language in constituting status by considering the question of "naming marriage" in the same-sex marriage debate, whether same-sex couples otherwise entitled to the benefits of marriage are and should be entitled to the term "marriage," alongside the persistently gendered practices of "marital naming," by which women almost universally adopt their husbands' last names upon marriage, despite the formal freedom of women to retain their names and of men to adopt their wives' last names. While women currently enjoy formal legal control over their last names, the legacy of mandated marital name change endures. Recent data suggest this practice may even be on the rise among the college-educated women who have been most likely to retain their names. ${ }^{4}$ The nearly universal practice of women adopting their husbands' names upon marriage attracts little attention as a measure of gender hierarchy within marriage. Assumed to occupy the domain of private choice, marital name change is deemed an inappropriate candidate for substantive evaluation.

In this Article, I explore how the question of "naming marriage" concerns the outer, gendered boundaries of marriage, while "marital naming" constructs the category of marriage as internally gendered. In other words, naming marriage addresses the gendered boundaries of who can participate in marriage, while marital naming concerns the gendered way in which participants of marriage may interact. Traditional naming practices--both naming marriage and marital naming together-define marriage as gender hierarchical.

In comparing these two areas, I observe that while the status-constituting capacity of language is assumed in the so-called "public" sphere (for example, when the government is conferring or withholding universally understood titles like "marriage"), it attracts little attention when "private" actors are involved (for example, when individual women are taking their individual husbands' last names).

This Article proceeds in five parts. Part I defines the concepts of status that animate this Article. Part II lays out the types of language that bear on status. This Part looks beyond family law to show how disputes over labels have helped minority groups challenge and redefine their status. Part III articulates a specific account of the way that the state's "public" use of language in the same-sex marriage debate reflects and reinforces hierarchy based on gender and sexual orientation. Part IV argues that marital-name practices embodied in women's name change similarly reflect and reinforce hierarchy based on gender. The seemingly "private" and trivial nature of name change masks the ways in which we perpetuate hierarchy through our continued participation in social practices that mimic a legally determined status quo. Part V considers the potential for these two forms of naming to facilitate the transformation of marriage into a less gendered institution.

My aim in considering these two areas together is not to argue that they are one and the same, but to highlight the ways in which the state's language practices, in "naming marriage," and individuals' language practices, in "marital naming," both reflect and reinforce a gender-hierarchical conception of marriage. I aim to explore how, in complementary ways, the state (through its legal control over the public use of the name "marriage") and individuals (through the name practices they pursue within

4. Recent research shows that among college-educated women, while name keeping rose sharply in the 1970s and 1980s, it declined in the 1990s. Claudia Goldin \& Maria Shim, Making a Name: Women's Surnames at Marriage and Beyond, 18 J. ECON. PERSP. 143, 144 (2004). 
marriage) reflect and reinforce a gendered conception of marriage. In considering "marital naming" in particular, I do not argue that the individual names that women retain or take on have universal meaning. I aim to evaluate overall how trends in the social practice of name change within marriage bear status implications and tie those implications to those inherent in naming marriage.

\section{DEFINING STATUS}

There are at least two conceptions of status that circulate in family law, one which can be called legal status, and the other social status. Legal status describes a position bearing a package of legal rights and obligations. Social status is a broader concept, referring to social positioning more generally. Implicit in the latter understanding of status are the concepts of recognition, relative privilege, and hierarchy. Social status can encompass legal status. In this Part, I lay out the relevance of both concepts of status to family law. As I will describe in the following Part, my argument focuses on the relationship between language and the broader concept of social status.

The basic understanding of status as a host of societal roles conferring packages of rights and responsibilities permeates family law. For example, the status of "parent" carries with it certain rights (for example, to direct the upbringing and education of one's children ${ }^{5}$ or the right to visitation) ${ }^{6}$ and responsibilities (for example, to parent in a manner the law deems "fit"). ${ }^{7}$ The law gives great deference to the "child's" best interests. ${ }^{8}$ In addition, those who comprise "families" are entitled to particular

5. See Wisconsin v. Yoder, 406 U.S. 205, 214 (1972) (recognizing fundamental right of parent to be free in decisions regarding child's religious upbringing); Pierce v. Soc'y of Sisters, 268 U.S. 510, 534-35 (1925) (finding a right of parents or guardians to "direct the upbringing and education of children under their control"); Meyer v. Nebraska, 262 U.S. 390, 400-01 (1923) (recognizing "the power of parents to control the education of their own [children]" and describing a child's education as the "natural duty of the parent").

6. See, e.g., Riepe v. Riepe, 91 P.3d 312, 315 (Ariz. Ct. App. 2004) (holding that a stepmother must prove that a child views her as a parent and not that she replaces or is superior to the child's legal parent in order to obtain in loco parentis visitation).

7. See Troxel v. Granville, 530 U.S. 57, 58 (2000) (noting that if parent is fit then she is presumed to be acting in the best interest of the child and the State should not intervene); Cynthia D. v. Superior Court, 851 P.2d 1307, 1313 (Cal. 1993) (recognizing state interest in protecting the child and upholding clear and convincing evidence standard as grounds for removing child from custody of unfit parent); In re Marriage of Carney, 598 P.2d 36, 42 (Cal. 1979) (stating that disability was not prima facie evidence of a father's unfitness as a parent); Williams v. Williams, 205 S.W.2d 949, 953 (Mo. Ct. App. 1947) (stating that welfare of child must be considered over natural privilege of parent in determining "proper custody").

8. See Guardianship of L.V., 38 Cal. Rptr. 3d 894, 901 (Cal. Ct. App. 2006) (rejecting argument that best interest of child standard as applied to parental termination interferes with fundamental rights of biological parent); Williams, 205 S.W.2d at 953 (finding welfare of the child most important factor in determining custody); Melinda G. Schmidt \& N. Dickon Reppucci, Children's Rights and Capacities, in CHILDREN, SOCIAL SCIENCE, AND THE LAW 76, 76 (Bette L. Bottoms, Margaret Bull Kovera \& Bradley D. McAuliff eds., 2002)(discussing the emergence and development of children's rights under the law); Barbara L. House, Considering the Child's Preference in Determining Custody: Is It Really in the Child's Best Interest?, $19 \mathrm{~J}$. JUV. L. 176, $177 \mathrm{n} .7$ (1998) (noting that best interest of the child includes, inter alia, "the wishes 
associational rights. $^{9}$

Given the importance of categories like "parent," "mother," "father," and "family," family law is often concerned with whether an individual or group resembles a particular status category enough to receive the package of benefits and duties accompanying that status. ${ }^{10}$ This inquiry frequently focuses on whether a relationship functions in such a way that it deserves to be treated as if it comports with legal form. ${ }^{\text {11 }}$

Marriage embodies the concept of status as a package of legal rights and responsibilities insofar as once parties agree to enter marriage, they cannot contract around or for particular rights and responsibilities. ${ }^{12}$ For example, the "duty of support" is not subject to individual alteration, as it would be if marriage operated in a strictly contractual regime. ${ }^{13}$ In other words, so long as parties are married, the benefits and duties of marriage issue forth and persist regardless of specific action.

of the child as to his custodian" and "the child's adjustment to his home, school, and community").

9. See, e.g., Alber v. Illinois Dep't of Mental Health \& Developmental Disabilities, $786 \mathrm{~F}$. Supp. 1340, 1368-73 (N.D. Ill. 1992) (discussing whether parents and their foster children held the same traits as a "natural family" in order to determine their constitutional rights of family association).

10. Family law is replete with cases addressing whether particular parties fit into status categories. See Elisa B. v. Superior Court, 117 P.3d 660, 671-72 (Cal. 2005) (ruling that a former same-sex partner was a "presumed mother" even though she was not a biological parent); K.M. v. E.G., 117 P.3d 673, 682 (Cal. 2005) (holding that an egg donor and her former samesex partner, the gestational mother, were both "mothers" of the resulting child); Johnson v. Calvert, 851 P.2d 776, 782 (Cal. 1993) (holding that the genetic parents of a child gestated through a surrogate were the "natural parents"); Chambers v. Chambers, No. CN99-09493, 2005 Del. Fam. Ct. LEXIS 1, at *12 (Del. Fam. Ct. Jan. 12, 2005) (holding that a former same-sex partner qualified as a "parent" under the Delaware statute even though she was not the biological mother).

11. See, e.g., Braschi v. Stahl Assocs. Co., 543 N.E.2d 49, 53-54 (N.Y. 1989) (discussing factors used in determining whether same-sex partner constituted "family member" of deceased); see also Michael H. v. Gerald D., 491 U.S. 110, 129 (1989) (discussing the right of the state to give preference to nonsterile, nonimpotent husband as "parent" to a child born during cohabitating marriage over biological father); Sheehan v. Flowers, 170 P.3d 288, 290 (Ariz. Ct. App. 2007) ("We have consistently defined 'parent' to mean 'one who begets offspring' or have used the term to refer to a child's biological or adoptive mother and father.").

12. See generally NANCY F. CotT, Public Vows: A History Of MARRIAGE AND THE NATION 101 (2000) (discussing marriage as more than a civil contract and embodying status and institutionalism); JONATHAN GOLDBERG-HILLER, THE LIMITS TO UNION: SAME-SEX MARRIAGE AND THE POLITICS OF CIVIL RIGHTS 81 (2002) (comparing status, which constricts by position, to contractual relationships, which involve "intentional arrangements"); CAROLE PATEMAN, THE SEXUAL CONTRACT 165-66 (1988) (discussing status as an inherent aspect of marriage in the seventeenth century and concluding that marriage is the acceptance of a particular status).

13. See Graham v. Graham, 33 F. Supp. 936,938 (E.D. Mich. 1940) (stating that a married couple could not contract out of their marital duties to each other); McGuire v. McGuire, 59 N.W.2d 336, 342 (Neb. 1953) (describing the purpose of the marriage relationship as the husband legally supporting his wife, said to be accomplished when the parties are cohabitating and the "home is maintained"); see also Reid v. Reid, 375 S.E.2d 533, 537 (Va. Ct. App. 1989) (noting that "a gradual breakdown in the marital relationship" does not justify desertion of a spouse (quoting Sprott v. Sprott, 355 S.E.2d 881, 883 (Va. 1987))); Twila L. Perry, The "Essentials of Marriage": Reconsidering the Duty of Support and Services, 15 YALE J.L. \& 
In contrast with a strictly legal view of status operates a larger conception of status. This understanding more broadly relates to social positioning. Implicit in status writ large are the notions of social recognition, relative privilege, and position in hierarchy.${ }^{14}$ In other words, this broader concept of status pertains to power, either its existence or its absence. When we discuss the relative power of social groups or of individuals, we often refer to their "statuses."

Social status is comprised of a host of concrete and more nebulous factors that establish positions of relative power. The legal rights and duties an individual may possess lend to the experience of status. For example, a substantial component of status in society is the right to vote. The possession of this right helps constitute the rightholder's experience of status in society.

Legal rights, however, do not account for all the ways status is constructed. These factors might also include class, education, race, ethnicity, sexual orientation, and geography. As I discuss in this Article, language and the labeling function it performs can also contribute to individuals' social status experience. The next Part focuses this discussion on labels as a form of language.

\section{DEFINING LANGUAGE}

The goal for this Part is twofold. First, I set forth the types of language on which my argument focuses-relational names and personal names. Second, I argue that the status-constituting function of language in family law comports with the manner in which language has acted as a site of struggle for greater social empowerment of marginalized groups. I explore various historical examples of groups resisting and redefining their status positions through language. These linguistic struggles have proceeded from the assumption that language has the capacity to affect or constitute status.

Relational names and personal names are two principal types of language that intersect with family law. By "relational names," I mean the words used to mark particular family law categories, such as "marriage," "wife," "husband," "family," "parent," and "child." I focus primarily on the relational names that have received the most attention in the same-sex marriage debate- "marriage" and "civil union." By "personal names," I refer most specifically to surnames - names used to identify and differentiate individuals.

These two examples of language in family law deserve particular attention because of their pervasive, yet little-examined, nature. They each act as basic forms of identification of the relationships and people to whom they are attached by distinguishing different types of relationship categories as well as different individuals. In this sense, they each serve as "labels," which, defined in the most conventional sense, are "descriptive or identifying word[s] or phrase[s]." Accordingly, at the very least, language performs a meaningful identifying function in family law. This Article

FEMINISM 1, 3 (2003) (focusing on the "duty of support and services" as a "legal obligation[] of the ongoing marriage").

14. See MERRIAM-Webster's Collegiate Dictionary 1220 (Frederick C. Mish, et al. eds., 11 th ed. 2003) (defining "status" as (a) "position or rank in relation to others"; or (b) "relative rank in a hierarchy of prestige").

15. Id. at 694 . 
is concerned, however, with the more difficult question of what function language plays in contributing to the construction of status in family law.

This examination of the function of language in family law arises against the backdrop of scholarly and political interest in the substantive consequences of language for individuals' experiences of power and disempowerment. Feminist linguists have written about the social construction of gender and femininity through expectations about how women talk and how women are talked about. ${ }^{16}$ Relatedly, struggles over language in other social contexts have emerged from an understanding that labels constitute social categories of difference. For example, the scholarly work on the sociology of deviance that emerged in the 1950s and 1960s has grounded our understanding of labels as capable of affirmatively constructing categories, rather than merely describing preexisting categories. The sociology of deviance looked in part at the application of "deviant labels" to particular social actors and at the construction and promotion of definitions of deviant behavior. ${ }^{17}$

Martha Minow's writing on social difference describes labels as a means of placing individuals and groups into varying categories that inscribe their relative social power. ${ }^{18}$ According to Minow,

[h] uman beings use labels to describe and sort their perceptions of the world. The particular labels often chosen in American culture can carry social and moral consequences while burying the choices and responsibilities for those consequences.

Language and labels play a special role in the perpetuation of prejudice about differences. ${ }^{19}$

Language, therefore, assists in the social engineering of categories "used to label people and assign them to particular social positions as if that assignment were compelled by their nature." 20 The power of these categories lies in the sense that they are somehow presocial and not constructed.

16. See, e.g., Robin Tolmach Lakoff, LANGUAGE AND Woman's Place (Mary Bucholtz ed., Oxford Univ. Press rev. \& expanded 2004).

17. Scott Phillips \& Ryken Grattet, Judicial Rhetoric, Meaning-Making, and the Institutionalization of Hate Crime Law, 34 LAW \& SoC'Y REv. 567, 570-72 (2000) (citing studies in sociology of deviance); see also Kai T. Erikson, Notes on the Sociology of Deviance, 9 Soc. PROBS. 307, 308 (1962) ("Deviance is not a property inherent in certain forms of behavior; it is a property conferred upon these forms by audiences which directly or indirectly witness them." (emphasis omitted)); D.L. Rosenbaum, On Being Sane in Insane Places, 179 SCIENCE 250, 252-54 (1973) (discussing experiment to test significance of labels, in which person identified as schizophrenic was unable to convince observers that he was not mentally ill).

18. See Martha Minow, Making All the Difference: Inclusion, Exclusion, and AMERICAN LAW 4, 6 (1990).

19. Id.

20. Martha Minow, Incomplete Correspondence: An Unsent Letter to Mary Joe Frug, 105 HARV. L. REV. 1096, 1097 n.4 (1992). 
Acting on an assumption that words can constitute and reflect social power and identity, historically marginalized groups have waged efforts to enhance their social positioning on the battleground of language. The civil rights and gay rights movements have each witnessed the emergence of new descriptive terms to resist dominant categories and to forge new social identities. In the late 1950 s and early $1960 \mathrm{~s}$, the term "Negro" gave way to "black," which was favored by groups such as the Black Muslims and Black Panthers. ${ }^{21}$ Although it had its critics, the term "black" was a symbol for "racial pride, militancy, power, and rejection of the status quo."22 The term was "largely unchallenged" from the early 1970 s to the late 1980 s. $^{23}$ In December 1988 , at a meeting of black leaders in Chicago, Ramona H. Edelin, the president of the National Urban League, recommended that "African American" replace "black." spokesperson for the National Urban League, Jesse Jackson justified the switch by explaining,

[j]ust as we were called "colored," but were not that, and then "Negro," but were not that, to be called "black" is just as baseless. Just as you have Chinese Americans who have a sense of roots in China ... or Europeans, as it were, every ethnic group in this country has a reference to some historical culture base. ... There are Armenian Americans and Jewish Americans and Arab Americans and Italian Americans. And with a degree of accepted and reasonable pride, they connect their heritage to their mother country and where they are now. ${ }^{25}$

A similar concern with nomenclature has animated the Asian-American rights movement. In the mid-nineteenth century, persons of Chinese descent, primarily males, began emigrating to the United States for the first time in substantial numbers. ${ }^{26}$ Between 1880 and 1910, Japanese families began to arrive on American shores in significant numbers as well. ${ }^{27}$ Americans saw these two groups as largely interchangeable and applied the term "Oriental" to both groups. ${ }^{28}$ In the $1970 \mathrm{~s}$, academics and community leaders began to use the term "Asian-American" to replace "oriental."29 Edward Said has argued that the term "oriental" conjures stereotypes of the mysterious and "the exotic, the "Other.",30 This "quaint term" has since been rejected by the Asian-American community. ${ }^{31}$ Although "Asian-American" is "an artificial concept," as it does not refer to any one place on a map, but instead encompasses the identities of Armenians, Persians, Asian Indians, Chinese, Japanese,

21. Tom W. Smith, Changing Racial Labels: From "Colored" to "Negro" to "Black" to "African American," 56 PUB. OPINION Q. 496, 499 (1992).

22. Id.

23. Id. at 503 (stating that a majority of blacks, black organizations, and surveys utilized the term "black").

24. Id.

25. Id. at 503, 507. See id. at 507-08 for further justifications and criticisms of the switch.

26. ERIC K. Yamamoto, MARgaret ChON, CaROl L. IZUMI, JeRry KaNG \& FranK H. WU, RACE, RIGHTS, AND REPARATION: LAW AND THE JAPANESE AMERICAN INTERNMENT 32 (2001).

27. Id. at 34 .

28. Id.

29. Frank H. Wu, Yellow: Race in America Beyond Black and White 306 (2002).

30. Id. (citing EDWARD SAID, ORIENTALISM 5 (1978)).

31. Id. (“'Oriental' is more appropriate for rugs than for people."). 
and Pacific Islanders, among others, ${ }^{32}$ activists and scholars argue that grouping these peoples together, though they may have vastly different cultural heritages, can be beneficial at times. Frank Wu points to Chicago, where Asian-American community groups "work together regularly across ethnic lines," because the communities are individually "too small to sustain themselves." 33

The lesbian, gay, bisexual, transgender (LGBT) movement has similarly engaged in efforts to gain command over self-descriptive terms. The term "queer" was used by homosexual men until it was gradually replaced by "gay"- - a development which began during the $1930 \mathrm{~s}$ and was complete by the end of the $1940 \mathrm{~s} .{ }^{34} \mathrm{By}$ the $1950 \mathrm{~s}$, "queer" referred to "a homosexual of either sex" 35 and constituted an "insulting slur that was taboo in most standard use." ${ }^{, 36}$ By the late 1930 s or early 1940 s, the term "gay" became the "preferred self-referent among homosexual men," but remained "coded language" until the 1950s. ${ }^{37}$ The term "gay" became the "identifier of choice" and caught on universally in the late 1960 s with the rise of the gay liberation movement. ${ }^{38}$ According to Steven Epstein,

The late 1980s marked the adoption, in various circles, of the word queer as a new characterization of "lesbian and gay" politics and, indeed, as a potential replacement for the very terms lesbian and gay. The term was explicitly associated with the activist group Queer Nation, which sprang up in dozens of cities around the United States; more generally, it reflected new political tendencies and cultural emphases, particularly in a younger generation of migrants to the established lesbian and gay communities. ${ }^{39}$

This focus on self-descriptive terms in the civil rights movements of marginalized groups is consistent with social constructionist understandings of the development of social categories. In her work on the national census, Naomi Mezey has discussed how categorizing people under labels in the census has historically called new groups into being. ${ }^{40}$ In focusing on self-descriptive terms, marginalized groups like AfricanAmericans, Asian-Americans, and LGBT individuals have responded to language's

32. Id. at 314 .

33. Id.

34. Jacinth Samuels, Dangerous Liaisons: Queer Subjectivity, Liberalism and Race, 13 Cultural Stud. 91,98 (1999).

35. Id. (quoting DiCTIONARY OF AMERICAN SLANG 415 (Harold Wentworth \& Stuart Berg Flexner eds., 1975)).

36. Id. (citing Kenneth G. Wilson, The Columbia Guide to Standard American ENGLISH 354 (1993)) (endnote omitted).

37. Tamarah Cohen, "Gay" and the Disappearing [+Female], 9 THE GAY \& LESBIAN REV. WORLDWIDE 22, 22 (2002).

38. Ann Bannon, Why Are We "Gay"? The History of a Small Adjective, LAMBDA Book REP., Sept. 2002, at 26, 27; see also Cohen, supra note 37, at 22 (stating that not until the advent of the gay and lesbian movement in the 1960s did the term gay "acquire[] its dual function as a generic (or pseudo-generic) referent for bothmen [sic] and women").

39. Steven Epstein, A Queer Encounter: Sociology and the Study of Sexuality, 12 Soc. THEORY 188, 194-95 (1994) (citations omitted) (emphasis in original).

40. See Naomi Mezey, Erasure and Recognition: The Census, Race and the National Imagination, 97 Nw. U. L. REV. 1701, 1701-02 (2003). 
capacity to reflect and shape the realities and aspirations of each group's political and social experience.

The capacity of language to constitute social categories and experiences of power, as explored by scholars and activists in other contexts, serves as the backdrop for my argument that family law presents a rich (and unexplored) terrain in which to examine the influences of language on status.

\section{NAMING MARRIAGE}

The debate over whether same-sex unions are entitled to the relational name "marriage," as opposed to other names like "civil union," is indeed a debate about language; more precisely, it is about the significance of language to status. Recent case law on same-sex marriage reflects an assumption that relational names are status themselves. ${ }^{41}$

I do not necessarily agree that relational names are themselves status, but language practices (for example, selecting different terminology), particularly when used by the state, have direct status consequences, more so than the current literature on same-sex marriage contemplates. I focus on the claim, made more or less explicitly in recent same-sex marriage cases, that regardless of the legal benefits and privileges conferred, "language matters." 42

A state-enforced difference in terminology such as that between "marriage" and "civil union" affects same-sex couples' status because it both reflects and reinforces their marginalized status relative to opposite-sex couples. In contrast with more presumably "private" uses of language like marital naming, which I discuss in the next Part, ${ }^{43}$ linguistic differential treatment in the same-sex union context is assumed by most who favor some form of marriage equality rights for same-sex couples to have status consequences. This is precisely because the state is the speaker, raising the stakes of language to the level of public recognition of same-sex couples' equal status.

It is important to clarify that my argument in favor of conferring the title "marriage" to same-sex unions is based on the unequal status that results from differential linguistic treatment. This is distinct from an argument based on a view that marriage is inherently valuable as an institution or that the label "marriage" is inherently meaningful. I am sympathetic with the arguments raised by those who urge marriage equality but challenge the primacy of marriage.

\section{A. The Language of Same-Sex Marriage}

A major issue that has emerged in the same-sex marriage debate is whether, in jurisdictions where courts have held that same-sex couples are entitled to the rights, privileges, and benefits of marriage, the legal institution into which these couples enter should be called "marriage," or should be given another designation like "civil union." In these cases, the sole issue is one of nomenclature, as the package of legal rights and obligations made available to same-sex couples is otherwise identical to that offered to

41. See, e.g., Lewis v. Harris, 908 A.2d 196 (N.J. 2006).

42. Id.at 226.

43. See infra Part IV. 
opposite-sex couples. Major cases in Connecticut, California, New Jersey, and Massachusetts have all squarely addressed the question of whether granting same-sex couples the right to the benefits of marriage also means granting the right to the relational name "marriage."

The Supreme Judicial Court of Massachusetts broke major ground for the marriage equality movement in 2003 when it held in Goodridge v. Department of Public Health that "[1]imiting the protections, benefits, and obligations of civil marriage to oppositesex couples violates the basic premises of individual liberty and equality under law protected by the Massachusetts Constitution." ${ }^{44}$ This conclusion, however, left that state's legislature uncertain as to whether any civil regime offering the "protections, benefits, and obligations of civil marriage" to same-sex couples needed to be called "marriage" as well. In In re Opinion of the Justices to the Senate, the Massachusetts Supreme Court set out to resolve this uncertainty when it considered whether granting "civil union" status would comply with the court's decision in Goodridge. ${ }^{45}$ In evaluating a proposed legislative bill that would apply the title "marriage" to oppositesex couples and "civil union" to same-sex couples, the Massachusetts Supreme Court concluded that this difference in terminology would violate the state's constitution. ${ }^{46}$

A state supreme court again encountered the question of nomenclature in Lewis $v$. Harris in 2006. In Lewis, the New Jersey Supreme Court held that the state's constitutional equal protection guarantee required the provision of the rights, benefits, and obligations of marriage to same-sex couples. ${ }^{47}$ The majority, however, declined to decide this question, choosing to characterize it as a legislative matter. ${ }^{48}$ In reaching this decision, the majority separated the question of whether same-sex couples are entitled to the rights of marriage from the question of whether they possess the right to the title "marriage." was one of "constitutional magnitude."

In 2008, in In re Marriage Cases, the California Supreme Court held that state statutes that applied the title "marriage" to opposite-sex couples and "domestic partnership" to same-sex couples, for identical legal rights, privileges, and benefits, violated the state's constitutional equal protection guarantees. ${ }^{51}$

And recently, in Kerrigan v. Commissioner of Public Health, the Connecticut Supreme Court deemed the issue of whether same-sex couples were entitled to the

44. 798 N.E.2d 941,968 (Mass. 2003).

45. 802 N.E.2d 565, 571-72 (Mass. 2004).

46. Id.

47. Lewis, 908 A.2d at 223.

48. Id.

49. Id. at 200 ("In this case, we must decide whether persons of the same sex have a fundamental right to marry that is encompassed within the concept of liberty guaranteed by Article I, Paragraph 1 of the New Jersey Constitution. Alternatively, we must decide whether Article I, Paragraph 1's equal protection guarantee requires that committed same-sex couples be given on equal terms the legal benefits and privileges awarded to married heterosexual couples and, if so, whether that guarantee also requires that the title of marriage, as opposed to some other term, define the committed same-sex legal relationship.").

50. Id. at 222 .

51. 183 P.3d 384, 452-53 (Cal. 2008). 
label "marriage," as opposed to "civil union," as relating to a "constitutionally cognizable injury." 52

Each of these cases invokes the question: how and why is language significant in the debate over marriage equality?

\section{B. The Public Nature of Naming Marriage}

The more "public" language practices appear to be, the more we assume a deep connection between language and status. What makes language practices "public"? The labeling of marriage or marriage-like institutions serves as an example of a public language practice, insofar as the state's role as speaker is key to the connection assumed between language and status. In the same-sex marriage context, the state is perceived as the relevant speaker, rather than private individuals, because the issue at stake is public recognition of same-sex unions. The state's language practices bear directly on the broader social status discussed above. ${ }^{53}$

The assumption of a deep connection between language and status in naming marriage does not, however, rest solely on the state being the relevant speaker. The "publicness" of the language practice proceeds from the universal nature of the terms at issue. While marital naming involves marital partners' decisions (or nondecisions) about what to do with their specific proper names upon marriage, the labels at issue in naming marriage are widely understood (or not, in the case of "civil union"); this universality of understanding drives the status inquiry in naming marriage.

In its decision in Lewis v. Harris, the New Jersey Supreme Court chose not to decide whether to confer the title "marriage" on same-sex couples; the majority declined to presume that the question of nomenclature was one of "constitutional magnitude," $" 54$ instead leaving this question up to the state legislature. Notably, the court left open the possibility that regardless of what New Jersey's legislature decided to do, same-sex couples could choose to use whatever language they wanted to describe their commitment: "However the Legislature may act, same-sex couples will be free to call their relationships by the name they choose and to sanctify their relationships in religious ceremonies in houses of worship." 55 Through this statement, the court drew a stark contrast between public and private language practices. The argument that same-sex couples can call themselves whatever they would like in private, however, misunderstands the underlying claim for linguistic parity in the marriage equality position. While same-sex couples may have the choice to call themselves "married" in private, this choice means little when public recognition of the equality of same-sex unions through the use of a universally understood term is being sought. Therefore, same-sex couples are denied full and meaningful access to the linguistic terms that shape and reflect their status. The state's official conferral of this title assists this full and meaningful access. ${ }^{56}$

52. 957 A.2d 407, 412 (Conn. 2008).

53. See supra text accompanying note 16 .

54. Lewis, 908 A.2d at 222.

55. Id. at 223 (emphasis added).

56. The state's use of the term "marriage" is not the only use of this term that carries social meaning. For example, the private use of the term "marriage" can be understood as a meaningful threat to the status quo. Indeed, Shahar v. Bowers, 114 F.3d 1097 (11 th Cir. 1997) demonstrates 
While the same-sex marriage linguistic equality argument is based on the importance of language, this importance does not proceed from any inherent significance of the term "marriage." The role of language in the same-sex marriage debate is distinct from that in the marital-names context because language operates in an overtly public-regarding manner in the same-sex marriage context. Language is important in the same-sex marriage context precisely because it is distributed and controlled by the state as a means of conveying recognition and privilege, or, in other words, status. The state, in essence, has control over the status vocabulary that samesex couples seek to engage.

Same-sex couples' efforts to gain public recognition and privilege are evident in same-sex marriage plaintiffs' articulations of reasons for seeking the right to marriage. Affidavits-like the following by plaintiffs in Lewis v. Harris, in which the New Jersey Supreme Court held that same-sex couples must be afforded equal treatment to that of opposite-sex couples-speak of the desire for social recognition:

Alicia and I live our life together as if it were a marriage. I am proud that Alicia and I have the courage and the values to take on the responsibility to love and cherish and provide for each other. When I am asked about my relationship, I want my words to match my life, so I want to say I am married and know that my relationship with Alicia is immediately understood, and after that nothing more needs [sic] be explained. ${ }^{57}$

The ability to call oneself married privately is not the right being sought here. Instead, this plaintiff is seeking entrance into a publically sanctioned vocabulary.

In other words, same-sex couples pursuing marriage equality seek the ability to use a common "public" language of intimate relationships, controlled by the state. As explained by another plaintiff in Lewis:

My parents long to talk about their three married children, all with spouses, because they are proud and happy that we are all in committed relationships. They want to be able to use the common language of marriage to describe each of their children's lives. Instead, they have to use a different language, which discounts and cheapens their family as well as mine[, because I have a same-sex partner and cannot be married]. ${ }^{58}$

Justice Poritz's dissent in Lewis v. Harris, in which she argued for applying the term marriage (while the majority left the question of terminology to the state legislature), ${ }^{59}$ suggests the desire of same-sex couples to disrupt the state's control over the public language of intimacy. "By those individual and personal statements, plaintiffs express a

the social and political disruption posed by the "private" use of the term "marriage" by same-sex couples, who have not received the stamp of public approval for this use. In Shahar, the plaintiff "married" another woman in a religious ceremony; upon learning of her marriage to another woman, which was not legally recognized, the defendant withdrew an offer of employment. Id. at $1100-01$.

57. Lewis, 908 A.2d at 226 (Poritz, J., dissenting) (quoting plaintiff's affidavit).

58. Id. (quoting second Plaintiff's affidavit) (alterations in original).

59. Id. at 223 (majority opinion). 
deep yearning for inclusion, for participation, for the right to marry in the deepest sense of that word." 60

The role of the state in the same-sex marriage debate must be explicitly acknowledged to understand why and how "language matters." The ability to use the term "marriage" in private and amongst friends does not meet the need for public recognition of same-sex couples. The marriage equality stance presupposes that language matters because the state controls the public vocabulary of intimate relations. The state is the relevant speaker and assumes control over language in the same-sex marriage context. As I discuss in the next two Subparts, the state's language practices participate in constructing same-sex couples' public status and reifying marriage's hierarchical status.

\section{Naming Marriage as Gendered}

Language is perceived to matter in same-sex marriage because the state is actively involved in using it to label different relationships. The state's control of the labeling of relationships locates these language practices in the domain of the public, in which social recognition of particular intimate relationships is at stake. In this Part, I further clarify the significance of language to status in this "public" context. First, I set forth the agreement on both sides of the marriage debate that language matters from a status perspective. Second, I contend that the debate over language in same-sex marriage revolves around the differences in designations applied by the state, rather than on the particular use of the term "marriage." Third, I argue that state-enforced differences in terminology perform two interrelated functions in constituting status: reflecting and reinforcing the view of marriage as a status rooted in sex difference. Consequently, they reinforce the marginalized social status of same-sex couples and LGBT individuals relative to heterosexuals.

Both sides of marriage equality discourse assume the value of language in the samesex marriage debate. Neither side of the debate challenges the claim that "what we 'name' things matters, language matters." ${ }^{, 61}$ Underlying the marriage equality position is the claim that equality and public recognition are contained in the term "marriage." For example, according to the majority in Lewis, "the word marriage itselfindependent of the rights and benefits of marriage-has an evocative and important meaning to both parties." ${ }^{22}$ For those in favor of same-sex marriage, that meaning includes a sense of privilege, recognition, and inclusion. For example, in its brief submitted as amicus curiae in the case before the Connecticut Supreme Court considering the constitutionality of that state's civil union scheme, Kerrigan $v$. Commissioner of Public Health, Lambda Legal Defense Fund argued that while civil union status provides the legal rights of marriage, it "preserves a privileged status for the majority and forces the minority into a distinct, lesser status" ${ }^{63}$ and "does not

60. Id. at 226 (Poritz, J., dissenting).

61. Id.

62. Id. at 221.

63. Brief of Amicus Curiae Lambda Legal Defense and Education Fund, Inc. at 6, Kerrigan v. Comm'r of Pub. Health, 957 A.2d 407 (Conn. 2008) (No. 17716). 
temper the harm suffered by a couple who wish to convey most accurately what their relationship means, using the one term that is universally understood: marriage."64

Despite an apparent trivializing attitude toward language, even the anti-same-sex marriage position is based on a conviction in the status-constituting capacity of language. Those who oppose or remain in doubt about conferring the title of "marriage" on same-sex couples often attempt to minimize the significance of the dispute over wording. These attempts, however, ultimately reinforce the significance of language. Such arguments appear in dissent in Opinion of the Justices to the Senate and the recent California Supreme Court's opinion In re Marriage Cases, where the issue of labels is characterized as one merely of "naming rights" 65 and "only the names of those unions," naming as one not admitting to constitutional adjudication, the court did not do so out of a sense that the labeling issue is an insignificant one. On the contrary, the court deemed the application of the term "marriage" to same-sex couples receiving all other benefits and privileges of marriage so monumental that it would work a major change in the "shared societal meaning of marriage" and would "render a profound change in the public consciousness of a social institution of ancient origin." Just as same-sex marriage proponents contend that "names matter,"68 same-sex marriage opponents assume a similarly tight connection between words and their significance. As argued by the Family Research Council in Kerrigan, "If words have any meaning, they cannot be changed at the whim of a court to create new rights that have not previously existed."69

While it is not disputed that language matters, and as I have discussed above, the state's involvement in language matters a great deal for public recognition purposes, both sides of the debate over language in same-sex marriage tend to overstate the claim that the ability to use the term "marriage" lies at the crux of the debate.

The fundamental problem with the state's language practices is that the state uses different language for same-sex couples and opposite-sex couples, not that the state is unwilling to use the label "marriage" for all couples. There is a tendency in the marriage equality position to valorize the significance of the term "marriage" because of the primacy of the institution of marriage. The problem with the state's language practices when it uses two different relational names is not that the state is using the term "civil union" for but that it is using a separate label for same-sex couples.

Although labeling same-sex unions differently than opposite-sex unions does not affect the legal status of same-sex couples, from the narrow standpoint of legal rights and privileges, state-enforced differences in labeling in the same-sex marriage context perform two interrelated functions in constituting status. They reflect and reinforce the

64. Id. at 4.

65. In re Opinion of the Justices to the Senate, 802 N.E.2d 565, 572 (Mass. 2004) (also describing issue as whether it is unconstitutional under the Massachusetts constitution to use "the term 'civil union' instead of 'marriage' to identify otherwise identical package of State law rights and benefits to be made available to same-sex couples").

66. In re Marriage Cases, 183 P.3d 384, 470 (Cal. 2008) (Corrigan, J., concurring and dissenting) (emphasis in original).

67. Lewis, 908 A.2d at 222.

68. Brief of Amicus Curiae Lambda Legal Defense, supra note 63, at 5.

69. Brief of Amicus Curiae Family Research Council in Support of Defendants at 13-14, Kerrigan v. State, 909 A.2d 89 (Conn. Super. Ct. 2006) (No. CV-04 4001813). 
view of marriage as a status rooted in sex difference. Consequently, they reinforce the marginalized social status of same-sex couples and LGBT individuals relative to heterosexuals.

The linguistic difference reflects a societal commitment to the notion that same-sex couples are fundamentally different enough in the nature of their intimacy that the state should place them in a separate category from opposite-sex couples. As the Massachusetts Supreme Court suggested in Opinion of the Justices, if the State did not intend to treat these relationships differently, then why would it go to such lengths to draw a linguistic difference ${ }^{70}$ The implications of this question ring particularly true when faced with the web of justifications the state has offered for drawing such linguistic disparity. For example, states have asserted that applying "marriage" only to opposite-sex couples helps maintain a link between procreation and marriage. ${ }^{71}$ According to same-sex marriage opponents, this link is important because children are better off in homes with opposite-sex parents than same-sex parents. ${ }^{72}$ Linguistic differentiation, pursuant to this view, plays a role in "encourag[ing] the optimal environment for rearing the resulting children."73

Same-sex marriage opponents also see implications for broader social order in reserving the title "marriage" for opposite-sex couples. For instance, according to the dissent in In re Marriage Cases, the opposite-sex interpretation of marriage acts as a bulwark against a descent down a slippery slope toward allowing incestuous or polygamous unions. $^{74}$

The tenuous justifications offered for this linguistic disparity reflect the state's staunch commitment to maintaining sex difference in marriage. For those opposed to

70. In re Opinion of the Justices to the Senate, 802 N.E.2d at 570 ("If, as the separate opinion posits, the proponents of the bill believe that no message is being conveyed by eschewing the word 'marriage' and replacing it with 'civil union' for same-sex 'spouses,' we doubt that the attempt to circumvent the court's decision in Goodridge would be so purposeful.").

71. See, e.g., Goodridge v. Dep't of Pub. Health, 798 N.E.2d 941, 961 (Mass. 2003) (citing state's arguments that barring same-sex couples from civil marriage served state's interest in providing a "favorable setting for procreation" and ensuring the optimal setting for child rearing, which the department defines as "a two-parent family with one parent of each sex").

72. See id. at 962.

73. Brief of Family Research Council as Amicus Curiae at 11, Kerrigan v. Comm'r of Pub. Health, 957 A.2d 407 (Conn. 2008) (No. 17716).

74. See In re Marriage Cases, 183 P.3d 384, 463 (Cal. 2008) (Baxter, J., concurring in part and dissenting in part) ("The bans on incestuous and polygamous marriages are ancient and deep-rooted, and, as the majority suggests, they are supported by strong considerations of social policy. Our society abhors such relationships, and the notion that our laws could not forever prohibit them seems preposterous. Yet here, the majority overturns, in abrupt fashion, an initiative statute confirming the equally deep-rooted assumption that marriage is a union of partners of the opposite sex. The majority does so by relying on its own assessment of contemporary community values, and by inserting in our Constitution an expanded definition of the right to marry that contravenes express statutory law. That approach creates the opportunity for further judicial extension of this perceived constitutional right into dangerous territory. Who can say that, in ten, fifteen, or twenty years, an activist court might not rely on the majority's analysis to conclude, on the basis of a perceived evolution in community values, that the laws prohibiting polygamous and incestuous marriages were no longer constitutionally justified?'). 
same-sex marriage, the matter is quite simple: marriage is fundamentally rooted in its opposite-sex character. "The union of a man and a woman has defined marriage throughout the history of the English term "marriage.",75 The social commitment to maintaining sex difference in marriage has been interpreted as an equal rights violation by some supporters of same-sex marriage, who maintain that bans on same-sex marriage act as a form of sex discrimination. ${ }^{76}$

Not only do state language practices reflect a societal commitment to maintaining sex difference in marriage, the state's language practices in the same-sex marriage context reinforce the normative claim that the sex difference in marriage should be maintained at the exclusion of same-sex couples. Designating same-sex couples under a separate relational name communicates the message that same-sex relationships are qualitatively different, and implicitly less worthy of public approval, than opposite-sex unions, primarily because of the centrality of marriage to conventional social understandings of the family.

Family law scholars concerned about ensuring appropriate legal and state support for the reality of caregiving relationships and fostering pluralistic visions for intimacy have criticized family law's construction around marriage as its central organizing unit. For example, Martha Fineman has challenged the assumption underlying family law and policy that the main caregiving unit worthy of state support and social sanction is the marital unit. ${ }^{77}$ Similarly, Nancy Polikoff has criticized the extent to which the state communicates that it will best protect caregiving work performed within marriage. ${ }^{78}$ Each of these critiques proceeds from the assumption that family law and policy is based on marriage as the primary unit around which family law is and should be based.

Due to the socially and legally privileged position of marriage, exclusion from this institution means exclusion from the recognition and value assumed to be contained within this status. Although marriage itself has been subject to critique by even those who favor same-sex marriage, ${ }^{79}$ to the extent that marriage is available to any, the exclusion of some from this institution sends the message that those outside the bounds of marriage do not qualify for this privileged status.

By reflecting and reinforcing a conception of marriage rooted in sex difference, the state's language practices shape the marginalized social status of lesbians and gays relative to heterosexuals. Through language, the state designates some relationships as

75. E.g., Brief of Family Research Council as Amicus Curiae, supra note 74, at 5.

76. See Baehr v. Lewin, 852 P.2d 44 (Haw. 1993), superseded by constitutional amendment, HAW. CoNST. amend. I, $\S 23$ (holding that the state's opposite-sex marriage requirements violated the Hawaii constitution's equal rights amendment).

77. See, e.g., MARTHA AlberTsOn Fineman, THE Neutered Mother, THE SeXual Family AND Other TWENTIETH Century Tragedies 117-89, 213-17, 226-35 (1995); Martha Albertson Fineman, Why Marriage?, 9 VA. J. Soc. PoL'y \& L. 239, 244-46 (2001).

78. Nancy D. Polikoff, We Will Get What We Ask For: Why Legalizing Gay and Lesbian Marriage Will Not "Dismantle the Legal Structure of Gender in Every Marriage," 79 VA. L. REV. 1535, 1546 (1993).

79. For example, Katherine Franke has critiqued the focus on marriage equality because of its antipluralistic tendency and its tendency to rely on domesticated couples as the caregiving standard, although she still argues that same-sex couples should be given access to marriage, to the extent that marriage is available. See Katherine M. Franke, The Politics of Same-Sex Marriage Politics, 15 COLUM. J. GENDER \& L. 236, 239 (2006). 
deserving the social status associated with a valued family institutional form and others as less deserving in this regard. Language, therefore, perpetuates difference and hierarchy- "[u]ltimately, the message is that what same-sex couples have is not as important or as significant as 'real' marriage, that such lesser relationships cannot have the name of marriage." $" 80$

\section{MARTTAL NAMING}

In contrast with the issue of same-sex marriage, in which most advocates and commentators assume to some degree that language has substantive implications, the topic of marital names is one area in family law that has largely been overlooked in recent years. This is most likely because, whereas in same-sex marriage, language operates in a public way to control, through state action, the privileged status to which individuals are entitled, marital names-specifically, the near-universal practice of women adopting their husbands' last names - appear to operate in the private domain of individual choice. In this Part, I complicate the "choice" that presumably distinguishes one language context from another, bringing the two areas closer together than they might first appear. I also argue that in marital naming, language shapes status by reflecting and reinforcing hierarchical conceptions of marriage, similarly to the way it does in same-sex marriage.

\section{A. Moving from Public to Private}

While public recognition of equality may appear more overtly at stake in the samesex marriage context, the popular identification of marital last names as a question of personal choice divests it of any perceived public status implications. Debates over women's surnames have historically borne on state recognition of women's equality insofar as the state has denied women's equality by mandating the adoption of one's husband's last name. To the extent that the goal of the marital-names battles was gaining state recognition of women's equality, the popular wisdom is that this goal has been reached because women now formally have the power to choose.

\section{Trends in Women's Names}

This Subpart outlines briefly the current practices of name change with which my argument is concerned. The removal of formal legal impediments to women retaining their names upon marriage has made it easier for women to keep their names, and more women are doing so today than forty years ago. ${ }^{81}$ Despite the removal of formal legal

80. Lewis v. Harris, 908 A.2d 196, 226-27 (N.J. 2006) (Poritz, J., dissenting); see also In re Marriage Cases, 183 P.3d 384, 452 (Cal. 2008) ("[T] he statutory provisions that continue to limit access to [the designation of 'marriage'] exclusively to opposite-sex couples ... likely will be viewed as an official statement that the family relationship of same-sex couples is not of comparable stature or equal dignity to the family relationship of opposite-sex couples."); In re Opinion of Justices, 802 N.E.2d 565, 570 (Mass. 2004).

81. According to a 2000 study by Laurie K. Scheuble, Katherine Klingermann, and David R. Johnson, there was a dramatic increase in the prevalence of women choosing nonconventional names (hyphenating or keeping name) between 1966 and 1996. Laurie K. 
barriers to women's name keeping or pursuing other naming practices, nearly all American women still adopt their husband's surname upon marriage-according to some studies, as many as $90 \%$ - and virtually no men change their names upon marriage. ${ }^{82}$ Of the $10 \%$ of women who do not take their husband's surname, $5 \%$ hyphenate, $2 \%$ retain their birth names, and the remaining $3 \%$ use some other alternative. ${ }^{83}$ Other studies suggest that the fraction of maiden-name retainers may even be smaller than this $2 \%$. A 1995 national study found that only $1.4 \%$ of married adult couples included wives who retained their birth names or hyphenated. ${ }^{84}$

The demographic profile of women who pursue various name options upon marriage has been the subject of considerable inquiry. ${ }^{85}$ In a national study of married adults and their adult offspring, David Johnson and Laurie Scheuble found that the major determinants of naming choices were geographical region, gender role traditionalism, the wife's career orientation, and educational attainment. ${ }^{86}$ Women who married later in life, were better educated, were more career-oriented, and held more liberal gender role values were more likely to use a nonconventional marital name. ${ }^{87}$

Confirming these findings, another study of nonconventional name practices by Scheuble, Johnson, and Katherine Klingermann spanning from 1966 to 1996 found that, in the $1980 \mathrm{~s}$ and $1990 \mathrm{~s}$, employed women were 1.5 times more likely to choose a nonconventional name than unemployed women. ${ }^{88}$ During this same period, women with higher levels of education were almost three times more likely to choose a

Scheuble, Katherine Kingemann \& David R. Johnson, Trends in Women's Marital Name Choice: 1966-1996, 48 NAMES 105 (2000) (surveying 2163 wedding announcements in the New York Times over thirty years). From 1990 to 1996, women were almost twenty-seven times more likely to take a nonconventional name than women married between 1966 and 1971 . The percentage of female college graduates in the United States who kept their surnames upon marriage rose from about $2 \%$ to $4 \%$ around 1975 to just under $20 \%$ in 2001 . Goldin \& Shim, supra note 4 , at $143-44$.

82. David R. Johnson \& Laurie K. Scheuble, Women's Marital Naming in Two Generations: A National Study, 57 J. MARRIAGE \& FAM. 724 (1995) [hereinafter Johnson \& Scheuble, Naming in Two Generations]; Laurie K. Scheuble \& David R. Johnson, Marital Name Change: Plans and Attitudes of College Students, 55 J. MARRIAGE \& FAM. 747 (1993) [hereinafter Scheuble \& Johnson, College Students]; Scheuble et al., supra note 81; Elizabeth A. Suter, Tradition Never Goes Out of Style: The Role of Tradition in Women's Name Practices, 7 COMM. REv. 57, 58 (2004) (citing Joan Brightman, Why Hillary Chooses Rodham Clinton, 16 AM. DEMOGRAPHICS 9 (1994)).

83. Suter, supra note 82, at 58.

84. Johnson \& Scheuble, Naming in Two Generations, supra note 82, at 727.

85. See generally Penelope Wasson Dralle \& Kathelynne Mackiewicz, Psychological Impact of Women's Name Change at Marriage: Literature Review and Implications for Further Study, AM. J. OF FAM. THERAPY, Fall 1981, 50, 74; Goldin \& Shim, supra note 4, at 143; Johnson \& Scheuble, Naming in Two Generations, supra note 82, at 724-32; Laurie K. Scheuble \& David R. Johnson, Married Women's Situational Use of Last Names: An Empirical Study, 53 SEX ROLES 143 (2005) (examining the practice of women using different last names depending upon the social situation); Scheuble et al., supra note 81, at 105-14.

86. Johnson \& Scheuble, Naming in Two Generations, supra note 82, at 724-32.

87. Id. at 727; see also Goldin \& Shim, supra note 4, at 156 (finding that brides in their mid-twenties had a much lower probability of "keeping"-about $12 \%$ to $14 \%$-relative to brides older than about thirty years in 1991).

88. Scheuble et al., supra note 81 , at 112. 
nonconventional last name. ${ }^{89}$ The religious nature of the marriage ceremony has also been found to play a role in name practices. For example, women married at home or in other nonchurch locations were two times more likely to choose a nonconventional name. ${ }^{90}$ Sociologists have also determined that women's career aspirations and orientation, increased average age at marriage, and a greater social emphasis are additionally responsible for the increase in women's name retention from the 1960 s to the 1990s. ${ }^{91}$

Marital names have renewed significance because there is reason to believe that the demographic profile of name practices may be shifting. While there are still more women retaining their last names today than before the feminist movement of the 1970 s, one recent study has observed a rise in the name-change rates among collegeeducated women in the $1990 \mathrm{~s} .{ }^{92}$

The practice of women's nominal identity shifting upon marriage is not unique to American culture. In Hungary, for example, women adopt a feminized version of their husbands' first and last names when they marry. ${ }^{93}$ But while I argue here that naming, as a form of language practice, is significant as a marker of gender hierarchy in the United States, this is not necessarily always the case across cultures. Different societies use different gender-hierarchy markers. In our culture and in many others, manner of dress also acts as an expression of gender difference and gender roles. In the United States, names have historically correlated with messages about gender, but this is not necessarily the case across the board. For example, in Korean society, women keep their surnames upon marriage-although this may not necessarily be a sign of gender equality. ${ }^{94}$ My focus in this Article is on the social, cultural, and historical forces that render language practices, particularly in the context of naming markers, of social hierarchy in the United States.

\section{Women's Names and the Private Domain}

The continued prevalence of women's name change overall and the observed rise in traditional name practices among some groups since the 1990s suggest that marital naming may no longer be perceived to possess the same political charge as a gender issue as it did during the first and second waves of feminism in the nineteenth and

89. Id.

90. Id. In their analysis of The New York Times wedding announcements, Claudia Goldin and Maria Shim found that a religious ceremony is associated with a lower probability of keeping one's surname. Goldin \& Shim, supra note 4, at 156.

91. Scheuble et al., supra note 81 , at 105.

92. Goldin \& Shim, supra note 4, at 144.

93. See BÉla KÁLMÁN, THE WORLD OF NAMES: A STUDY IN HUNGARIAN ONOMATOLOGY 64 (1978). In Hungary women take their husband's full name, adding "-ne" to the end of his name. For example, the wife of Tar Jakab would become Tar Jakabne, which is the functional equivalent of Mrs. Tar Jakab in English. Id.

94. See Sang-Hun Choe, Sexual Roles Still the Rule in South Korean Society, L.A. TIMES, Oct. 28, 2001, at A24. Korean women do not take their husband's name because they do not share the same bloodline; "[t]he civil code defines family members as descendants along the male line." Id. 
twentieth centuries. Instead, marital names are often viewed as occupying the private domain of personal choice.

Postfeminist writers like Katie Roiphe have characterized women's name change as subject merely to women's individual choice. She writes of the freedom that women today experience to do what they will with their names:

These days, no one is shocked when an independent-minded woman takes her husband's name, any more than one is shocked when she announces that she is staying at home with her kids. Today, the decision is one of convenience, of a kind of luxury-which name do you like the sound of? What do you feel like doing? The politics are almost incidental. Our fundamental independence is not so imperiled that we need to keep our names. The statement has, thanks to a more dogmatic generation, been made. Now we dabble in the traditional. We cobble together names. At this point-apologies to Lucy Stone, and her pioneering work in name keeping-our attitude is: Whatever works. ${ }^{95}$

The rhetoric of freedom and choice similarly emerges in contemporary personal explanations of name change. For example, one twenty-nine-year-old woman who is a research coordinator at the University of Pittsburgh said of her decision to change her name, "I'm the same person, and I'm still going to act or do what I always have .... Just because I've taken his name doesn't mean I've become this subordinate woman who's not going to act on my own volition.",96

Claudia Goldin and Maria Shim, authors of a study finding a decline in name retention among college-educated women, speculate that "surname-keeping seems less salient as a way of publicly supporting equality for women than it did in the late 1970s and 1980s."97 This explanation seems consistent, at least, with the rejection by professional women who change their names of the suggestion that name change indicates submission to male authority.

95. Katie Roiphe, The Maiden Name Debate: What's Changed Since the 1970s?, SLATE, Mar. 16, 2004, http://www.slate.com/id/2097231/ (emphasis in original). Roiphe also writes:

There's something romantic and pleasantly old-fashioned about giving up your name, a kind of frisson in seeing yourself represented as Mrs. John Doe in the calligraphy of a wedding invitation on occasion. At the same time it's reassuring to see your own name in a byline or a contract. Like much of today's shallow, satisfying, lipstick feminism: One can, in the end, have it both ways.

Id.

96. Anya Sostek, A Bride by Any Other Name: Scholars Wonder Whether Social Change Has Made Name Change Less Urgent, PITTSBURGH POST-GAZETTE, Nov. 7, 2005, at C1. Goldin and Shim also speculate that some of the women who changed their names in the 1980 s were responding to "peer pressure," while the women of today are "freer" to choose to retain their names. Goldin \& Shim, supra note 4, at 159. Given the problematic nature of "choice" in this context, this suggestion seems somewhat facile. Many, feminists and beyond, however, have discussed the problems of "choice" in the context of decisions that comport with existing status relationships and hierarchies. See, e.g., Elizabeth F. Emens, Changing Name Changing: Framing Rules and the Future of Marital Names, 74 U. CHI. L. REv. 761,764 (2007) (discussing the constraints on women's choices in the context of marital naming).

97. Goldin \& Shim, supra note 4, at 159. 
Current attitudes about naming may also reflect a greater sense of personal choice, which resonates with an increased sense that feminism means being able to do as one pleases, regardless of whether and how it comports with earlier versions of feminism. Although far from a cohesive movement, "third wave" feminism, mostly comprised of women who came of age after the second wave of feminism, seeks women's "freedom to live life as they choose." 98 This emphasis on freedom plays out in third wave approaches to issues pertaining to female sexuality and pornography, in which personal choice and power are assumed, in contrast with second wave feminists' concerns about structural constraints on the exercise of free will.$^{99}$ It is also consistent with the rhetoric of choice animating current discussions about women "opting out" of the workforce when they have children. ${ }^{100}$

98. Harold P. Southerland, "Love for Sale"-Sex and the Second American Revolution, 15 DUKE J. GENDER L. \& POL'Y 49, 117 (2008); see also Bridget J. Crawford, Toward a ThirdWave Feminist Legal Theory: Young Women, Pornography, and the Praxis of Pleasure, 14 MiCH. J. GENDER \& L. 99 (2007); Jennifer C. Nash, From Lavender to Purple: Privacy, Black Women, and Feminist Legal Theory, 11 CARDOzo WOMEN's L.J. 303 (2005); Dana Neacsu, The Wrongful Rejection of Big Theory (Marxism) by Feminism and Queer Theory: A Brief Debate, 34 CAP. U.L. REV. 125 (2005); Kathy A. Thomack, Centering Men's Experience: Norah Vincent's Self-Made Man Complicates Feminist Legal Theorists' Views of Gender, 15 BuFF. WOMEN'S L.J. 1 (2007).

99. See Katherine ANNe RoIPHe, The Morning After: SeX, Fear, and Feminism on CAMPUS (1993) (arguing that women have agency in date rape context); Crawford, supra note 98, at 139-41 (discussing young feminists' mostly positive view of pornography as a "healthy part of an overall sex-positive agenda"). In contrast, earlier feminists have argued that pornography does not embody personal choice or power, but rather the subordination of women. Andrea Dworkin, Against the Male Flood: Censorship, Pornography and Equality, 8 HARV. WOMEN's L.J. 1 (1985). Dworkin has argued that "pornography sexualizes violence against women," thereby encouraging sexual violence against woman. Crawford, supra note 98, at 136 (citing ANDrea DWORKIn, Pornography: MEN Possessing WOMEn (1981)). Similarly, Catherine MacKinnon has argued that pornography oppresses women by taking sexuality away from them and putting it into the hands of those that create the pornography. Catherine A. MacKinnon, Francis Biddle's Sister: Pornography, Civil Rights and Speech, Francis Biddle Memorial Lecture at Harvard Law School (Apr. 5, 1984), in CATHERINE A. MACKINNON, FEMINISM UNMODIFIED: DISCOURSES ON LIFE AND LAW 163, 171 (1987).

100. See, e.g., Lisa Belkin, The Opt-Out Revolution, N.Y. TIMES, Oct. 26, 2003, § 6 (Magazine), at 42; Erin Bryce, Staying at Home: Women Choose Motherhood as a Full-Time Career, SARASOTA HeRALD-TRIB., May 6, 2004, at H1; H.J. Cummins, Reporting in on "Opting Out"-A Study Contradicts a 2005 Report that Said More Professional Women Were Quitting Work After Hoving Kids, MiNNEAPOLIS STAR TRIB., Mar. 28, 2006, at D1; Caitlin Flanagan, How Serfdom Saved the Women's Movement, ATLANTIC, Mar. 2004, at 109; Caitlin Flanagan, To Hell With All That, NEW YORKER, July 5, 2004, at 38; Marilyn Gardner, The Truth Behind Women "Opting Out", Christian SCI. MONITOR, Oct. 30, 2006, at 13; E.J. Graff, The Mommy War Machine, WASH. Post, Apr. 29, 2007, at B1; Louise Story, Many Women at Elite Colleges Set Career Path to Motherhood, N.Y. Times, Sept. 20, 2005, at A5; Bill Torpy, Paths to Power: Women Today: Full-Time Mothers Trade Careers for Kids, ATLANTA J.-ConST., Apr. 8, 2003, at F1. 


\section{The Historically Public-Regarding Nature of Marital Naming}

The popular assumption that marital names are a matter of personal choice means that they are perceived as devoid of implications for public recognition of equality that are assumed in the same-sex marriage context. Debates over women's names, however, have historically been staked on public, societal recognition of women's equality. In this way, marital naming has shared concerns with naming marriage over public recognition of equality. Activists and scholars have argued that the state denied women's equality by mandating the adoption of one's husband's last name. This Subpart sets forth the legal framework for marital names that prevailed until feminist activism forced change in the 1970s and 1980s. This Part then discusses the extent to which the feminist movements of the nineteenth and twentieth centuries have viewed the denial of women's control over their names as a means of denying public recognition of women's equality to men, similar to the way that the same-sex marriage debate has centered on public recognition of the equality of same-sex couples and lesbians and gays.

\section{a. Legally Mandated Name Change}

Until the 1970s and 1980s, American law supported the assumption that women must take their husbands' last names upon marriage. As discussed by Una Stannard in her seminal work on the history of names in the United States, this standard was predicated on a misunderstanding of common law and the confusion of custom for law. ${ }^{101}$

English common law, which all but one American state followed for marital names purposes, traditionally contemplated a fluid approach to names. ${ }^{102}$ This approach gave

101. UnA StanNaRd, MrS MaN 95 (1977).

102. Pricilla Ruth MacDougall, The Right of Women to Name Their Children, 3 LAw \& INEQ. 91, 102-03 (1985). Louisiana follows civil law-"a married woman never loses her 'patronymic' name although 'she has the right to use her husband's name in all acts of her civil life and even of her commercial life." Id. at 102-03 n.19 (quoting 1 MARCEL PLAINIOL \& Georges Ripert, Traite ElementaIRE DE DroIt Civil. $\$ \S 390,392$, at 258 (1935)). Unlike in the common law system, which is based on the binding precedents of past decisions, the civil law system looks at strict codifications of laws, which are developed by the legislature and heavily influenced by outside jurists and their writings. JAMES G. APPLE \& ROBERT P. DEYLING, Federal Judicial Center, A Primer on the Civil-Law System 34 (1995). The civil law tradition came to Louisiana through its original French settlers, when the French monarchy declared that the territory would be governed by its civil law in 1712. David Grunning, Bayou State Bijuralism: Common Law and Civil Law in Louisiana, 81 U. DET. MERCY L. REv. 437, 442 (2004). In 1762, when Louisiana was given to Spain, the French civil law was replaced by the Spanish civil law. Id. The French briefly regained control of the territory in 1803 for less than one month, when the United States purchased it. Id. When the first American governor, William Claibourne, attempted to replace this civil law system with the American common law, he was met with fierce resistance from the Créole population of the territory who did not understand how the common law would operate, and feared it would lead to the eventual abolition of slavery, upon which their wealth depended. H. F. Jolowicz, Bench and Bar: The Civil Law in Louisiana, 21 TUL. L. REV. 491, 494 (1955). In an attempt to preserve their way of life, the Créoles in the legislature passed a law that tried "to define the sources of law that might 
all individuals the right to any surname ${ }^{103}$ Common law established that all persons had the right to use and be known for all legal and social purposes by surnames they chose as long as they did not do so for fraudulent purposes. ${ }^{104}$ "Fraudulent purpose" is most commonly referred to as the "intent to conceal one's person to avoid being recognized." 105

Although cases on marital names have frequently referred to a married woman's "legal name," the concept of a "legal name" was traditionally irrelevant in common law. According to the common law, "[i]n the absence of any restrictive statute, it is the common-law right of a person to change his name, or he may by general usage or habit acquire a name notwithstanding [its difference] from the one given him in infancy."106

This right was not limited to men. Common law allowed a man or woman to change his or her name at will, without a legal proceeding, by simply adopting a new name and becoming known by that name. ${ }^{107} \mathrm{~A}$ woman who acquired her husband's name did so by assumption and general use. ${ }^{108}$ Name-change statutes, such as those in current existence in many states, are meant to aid the common law right by providing a

be quoted in Louisiana," which ultimately became a "[d]igest of civil law, based mainly on one of the drafts for the Code Napoléon, but containing also some Spanish elements." Id. at 494-95.

103. Olive M. Stone, The Status of Women in Great Britain, 20 AM. J. CoMP. L. 592, 606 (1972).

104. MacDougall, supra note 102, at 103; see also HOMER H. CLARK, JR., THE LAW of DOMESTIC RELATIONS IN THE UNITED STATES 304-05 (2d ed. 1988). "In English law, contrary to the law of most countries, there are no rules about legal names. The surname of any person, male or female, is the name by which he or she is generally known, provided that the name was not assumed for any fraudulent purpose." Stone, supra note 103, at 606.

105. MacDougall, supra note 102, at 103; see also In re B., 366 N.Y.S.2d 98 (1975) (denying petition because it would lead to misrepresentation of condoned adultery); Hurley Name Case, 38 Pa. D. \& C.2d 146, 149 (C.P. 1965) (granting petition would facilitate adulterous relationship and was denied); Weinstein's Petition, 35 Pa. D. \& C. 227, 229-30 (C.P. 1939) (changing of name would assist petitioner in avoiding fraud charges under a separate alias); Jane M. Draper, Annotation, Circumstances Justifying Grant or Denial of Petition to Change Adult's Name, 79 A.L.R.3d 562, 587-88 (1977).

106. Loser v. Plainfield Sav. Bank, 128 N.W. 1101, 1103 (Iowa 1910) ("[T] here is no such thing as a 'legal name' of an individual in the sense that he may not lawfully adopt or acquire another, and lawfully do business under the substituted appellation. ... A man's name for all practical and legal purposes is the name by which he is known and called in the community where he lives and is best known.").

The purpose of a name is to identify the person. By the common law, since the time of William the Norman, a full name consists of one christian or given name, and one surname or patronymic.... No person is bound to accept his patronymic as a surname, nor his christian name as a given name, though the custom to do so is almost universal amongst English-speaking people, who have inherited the common law. A person may be known by any name in which he may contract, and in such name he may sue and be sued, and by such name may be criminally punished; and when a person is known by several names - by one as well as another-he may contract in either, and sue and be sued by the one in which he contracts, and may be punished criminally by either.

Schofield v. Jennings, 68 Ind. 232, 234-35 (1879).

107. Shirley Raissi Bysiewicz \& Gloria Jeanne Stillson MacDonnell, Married Women's Surnames, 5 CONN. L. REv. 598, 600-01 (1973); MacDougall, supra note 102, at 104.

108. MacDougall, supra note 102, at 105 n.28. 
mechanism for a formal record of a name change, but such records are not generally required for a legally effective name change. ${ }^{109}$

Despite common law's flexible attitude toward naming, the common law principle of coverture could have been interpreted to vitiate any incentive for women to maintain an identity independent of their husbands, thus effectively imposing a requirement for women to assume their husbands' names. ${ }^{10}$ According to the doctrine of coverture, at marriage a husband and wife became one such that the husband maintained his legal presence while the wife lost hers, resulting in "civil death." 111

The adoption of her husband's name was key to the merger of the wife's identity into the husband's. For example, Johann Gottleib Fichte, in The Science of Rights, stated:

Her own dignity requires that she give herself up entirely [to her husband] ... and should utterly lose herself in him. The least consequence is, that she should renounce to him all her property and all her rights. Henceforth she has life and activity only under his eyes and in his business. She has ceased to lead the life of an individual; her life has become a part of the life of her lover. (This is aptly characterized by her assuming his name.) ${ }^{112}$

In keeping with the principle of coverture, even with the passage of the Married Women's Property Acts ${ }^{113}$ in late nineteenth century England and in most U.S. states, women assumed their husband's surnames. ${ }^{114}$

109. Id at 104-05. Most states provide a statutory option to resume one's birth name after divorce. See D. Kelly Weisberg \& Susan Frelich Appleton, Modern Family Law 255-56 (3d ed. 2006). According to the English common law, a person can be known by multiple surnames, yet only one first, or "Christian," name. MacDougall, supra note 102, at 103-04.

110. Bysiewicz \& MacDonnell, supra note 107, at 600-01.

111. Barbara Allen Babcock, ANn E. Freedman, Susan Deller Ross, Wendy Webster Williams, Rhonda Copelon, Deborah L. Rhode \& Nadine Taub, Sex Discrimination and THE LAW: History, PRACTICE, AND THEORY 21 (2d ed. 1996) (“A wife could not enter into contracts, write wills, or sue or be sued in her own right. She could not legally manage or retain the fruits of her real property or acquire or keep personal property ....").

The oft-quoted Blackstone commentary on marriage explains this concept of civil death:

[T] he husband and wife are one person in law: that is, the very being of legal existence of the woman is suspended during the marriage, or at least is incorporated and consolidated into that of the husband: under whose wing, protection, and cover, she performs everything; ... and her condition during her marriage is called her coverture. Upon this principle, of a union of person in husband and wife, depend almost all the legal rights, duties, and disabilities, that either of them acquire by marriage.

WILLIAM BLACKSTONE, 1 COMMENTARIES *442 (emphasis in original).

112. J.G. FICHTE, THE SCIENCE OF RIGHTS 402 (A.E. Kroeger trans., Harper \& Row 1970) (1889).

113. The Married Women's Property Acts gave a few women with substantial property the capacity to manage and control that property after marriage without relying on equity arguments. Bysiewicz \& MacDonnell, supra note 107, at 601.

114. Id. There are, however, exceptions. See William C. Matthews Jr., Comment, Married Women and the Name Game, 11 U. RICH. L. REV. 121, 128 (1976) ("There were significant instances in which the wife and the husband held different surnames. It was even more common 
The disincentive imposed by coverture to attempt to forge a separate identity from one's husband through name retention evolved into a legal rule in case law originating in the late nineteenth century, which affirmatively stated that women adopted their husbands' last names upon marriage pursuant to common law. ${ }^{115}$ In the 1881 case often cited for this principle, Chapman v. Phoenix National Bank, ${ }^{116}$ the New York Court of Appeals stated: "For several centuries, by the common law among all English-speaking people, a woman, upon her marriage, takes her husband's surname."

Moreover, as recently as 1971, legal treatises like American Jurisprudence suggested that, under the common law, a woman had to adopt her husband's name. ${ }^{118}$

Building on precedent from the late nineteenth and early twentieth centuries, ${ }^{119}$ a number of state courts up to the 1970s and 1980s concluded that women adopted their husbands' surnames as a matter of law. ${ }^{120}$ Courts determining that common law

for the husband to adopt the wife's surname.").

115. See Chapman v. Phoenix Nat'l Bank, 85 N.Y. 437, 450 (Ct. App. 1881) ("[A woman's] maiden surname is absolutely lost, and she ceases to be known thereby."); see also In re Kayloff, 9 F. Supp. 176, 176 (S.D.N.Y. 1934) (citing Baumann v. Baumann, 165 N.E. 819, 821 (N.Y. 1929); Chapman, 85 N.Y. at 450); Bacon v. Boston Elevated Ry., 152 N.E. 35, 36 (Mass. 1926) (citing Chapman, 85 N.Y. at 449); Baumann v. Baumann, 165 N.E. 819,821 (N.Y. 1929) (citing Chapman, 85 N.Y. at 449).

116. 85 N.Y. at 437.

117. Id. at 450. Notably, Chapman did not pertain to married women's naming rights. The case dealt with whether the bank stocks owned by married woman Verina Chapman were rightfully seized by the United States government on the grounds that she was using the stock dividends to aid the Confederate Army. Id. at 448 . The court held that there was no evidence that Mrs. Chapman intended to use the stock dividends in the alleged manner. Id. at 449. Moreover, the court stated that she was never brought to court. Id. The notice of seizure listed "Ver. S. Moore," "Moore" being Mrs. Chapman's birth surname. Id. at 449-50. She could not have been recognized by this notice because her name had been Verina Chapman since her marriage. Id. at 450 .

118. 57 AM. JUR. 2D Name $\$ 9$ (1971).

119. See Chapman, 85 N.Y. at 449; see also Kayloff, 9 F. Supp. at 176 (citing Baumann, 165 N.E. at 821 ; Chapman, 85 N.Y. at 450 ); Bacon, 152 N.E. at 32 (citing Chapman, 85 N.Y. at 449); Baumann, 165 N.E. at 821 (citing Chapman, 85 N.Y. at 449).

120. Forbush v. Wallace, 341 F. Supp. 217 (M.D. Ala. 1971) (per curiam) (noting Alabama's adoption of a common law rule that a wife takes her husband's surname at marriage), aff'd without op., 405 U.S. 970 (1972); Kayloff, 9 F. Supp. at 176 (denying a request to have a certificate of naturalization issued in the applicant's birth name, despite the fact that the applicant was a professional musician well known under her birth name); Roberts v. Grayson, 173 So. 38, 39 (Ala. 1937) ("[A] married woman's name consists, in law, of her own Christian name and her husband's surname."); People ex rel. Rago v. Lipsky, 63 N.E.2d 642 (Ill. App. Ct. 1945) (requiring woman to reregister to vote after marriage because under custom and common law a woman abandons her birth name and takes her husband's surname at marriage); Bacon, 152 N.E. 35 (Mass. 1926) (denying recovery to a married woman for damages to ber car because it was registered in her birth name and therefore not considered legally registered by the court); Kelle v. Crab Orchard Rural Fire Prot. Dist., 83 N.W.2d 51, 54-55 (Neb. 1957) ("A married woman's name consists, in law, of her own Christian name and her husband's surname, marriage conferring on her the surname of the husband. Her correct first name is her maiden Christian name, and not the Christian name of her husband." (citing 38 AM. JuR. Name §10); In re Lawrence, 319 A.2d 793 (Bergen County Ct. 1974) (denying married woman's application to resume use of maiden name was without warrant under change of name statute), rev'd, 337 A.2d 
changed women's surnames as a matter of law would even often disregard a woman's longstanding professional use of her birth surname in considering petitions to continue using birth names. ${ }^{121}$

\section{b. Efforts Toward Public Recognition of Women's Equality Through Names}

The issue of women's control over their names occupied a prominent place in the agendas of both first and second wave feminism. ${ }^{122}$ Concern over women's names was rooted in the sense that the law and practice of marital names put in issue public recognition of women's equality and autonomy. ${ }^{123}$ In this way, debates over women's names resembled the debates over status and public recognition underlying the current same-sex marriage debate. To the extent that we collectively draw a distinction between same-sex marriage and marital names based on the public recognition of equal status at issue, debates over marital names have historically been deeply rooted in concerns about public recognition of women's equal status. ${ }^{124}$

For example, during feminism's “first wave," feminists focused on the extent to which the mandated loss of women's names upon marriage embodied the absence of autonomy and individual identity of women both within the family and in public life. In August of 1848, feminists at the second Women's Rights Convention in Rochester, New York, took up the question of women's names in a discussion of equality in marriage. In response to male attendees who questioned whether complete equality in marriage was practical, Cady Stanton said:

When a slave escapes from a Southern plantation ... he at once takes a name as the first step in liberty-the first assertion of individual identity. A woman's dignity is equally involved in a life-long name, to mark her individuality. We cannot overestimate the demoralizing effect on woman herself, to say nothing of society at large, for her to consent thus to merge her existence so wholly in that of another. ${ }^{125}$

49 (N.J. Super. App. Div. 1975) .

121. For example, in People ex rel. Rago v. Lipsky, the court considered a female attorney's petition for a writ of mandamus to require the city's board of election commissioners to permit her to remain registered to vote under her birth name. 63 N.E. $2 \mathrm{~d}$ at 642 . In denying the petition for writ of mandamus, the court viewed as "immaterial and irrelevant" the fact that petitioner had practiced her profession under her birth name, that she was commonly and widely known in the neighborhood as an attorney at law under that name, that she had used her birth name in local political activities and had been admitted to practice under her birth name, and that she would suffer substantial damage to her professional reputation if she were required to vote under her husband's surname. Id. at 647 . The court concluded that such facts had no bearing on the duty of the petitioner to register in accordance with the state's voter registration statute, which was consistent with what the court viewed as the common law rule that a woman takes her husband's surname upon marriage. $I d$.

122. For a discussion about the prominence of names issues in feminist movements, see infra Appendix.

123. Id.

124. For a discussion of the roots of nineteenth- and twentieth-century feminist name activism and its concern with public recognition of women's equality, see infra Appendix.

125. STANNARD, supra note 101. 
As in the first wave of feminism, struggles over marital names during the second wave of feminism served as a site for addressing women's social status and challenging law and society to recognize women's equality and autonomy. ${ }^{126}$ In this way, maritalnames struggles have functioned in a similar way as the same-sex marriage debate, insofar as both have centered on how language - through relational or personal names-bears on the state's public recognition of equal status of women or same-sex couples, respectively.

\section{From Public to Private Through Formal Law}

Today, women formally have the right to control their names. All states recognize a woman's right to retain her birth surname upon marriage. ${ }^{127}$ This right is supported by a web of statutes, cases, agency regulations, and state attorneys' general interpretations. $^{128}$

The Alabama Supreme Court's repudiation of Forbush v. Wallace ${ }^{129}$ in 1982 was the culmination of a line of cases from the 1970 s that formally recognized a woman's right to choose her surname. ${ }^{130}$ The Supreme Court's affirmance of Forbush ${ }^{131}$ brought

126. See infra Appendix for discussion of second wave feminism's approach to names.

127. WEISBERG \& APPLETON, supra note 109, at 255; see also Ball v. Brown, 450 F. Supp. 4 (N.D. Ohio 1977) (holding that a married woman's voter registration cannot be automatically canceled without determining whether the woman actually changed her name through marriage); Malone v. Sullivan, 605 P.2d 447 (Ariz. 1980) (finding error in a trial court's refusal to entertain a woman's divorce petition unless she amended her pleading to reflect her surname as her husband's); Sec'y of Commonwealth v. City Clerk of Lowell, 366 N.E.2d 717 (Mass. 1977) (holding that city and town clerks must respect the common law principle that people were free to change their names freely so long as there was no fraudulent intent); In re Lawrence, 319 A.2d 793 (Bergen County Ct. 1974), (denying a married woman's application to resume use of maiden name was without warrant under change of name statute), rev'd, 337 A.2d 49 (N.J. Super. App. Div. 1975); In re Halligan 361 N.Y.S.2d 458 (N.Y. App. Div. 1974) (holding that a married woman could use her birth name as her legal name; referring to the common law rule that one may change his/her name at will so long as there is no fraud, misrepresentation, or interference with the rights of others); Traugott v. Petit, 404 A.2d 77 (R.I. 1979) (holding that a divorced woman can register a motor vehicle using birth sumame); In re Erickson, 547 S.W.2d 357 (Tex. Civ. App. 1977) (holding that it is an equal protection violation to deny a name change back to maiden name); In re Miller, 243 S.E.2d 464 (Va. 1978) (finding confusion to creditors not sufficient to deny common law right allowing married woman to revert to her birth surname); Kruzel v. Podell, 226 N.W.2d 458, 460 (Wis. 1975) (stating that no law requires woman to take her husband's surname, custom merely suggests that she do so); Ronald A. Case, Annotation, Right of Married Woman to Use Maiden Surname, 67 A.L.R.3d 1266 (1975) (citing cases); CLARK, supra note 104, at 304-05 ("Today, however, the overwhelming weight of authority is that the married woman may retain her maiden name, or take what name she chooses, so long as her choice is neither fraudulent nor unlawful.").

128. See MacDougall, supra note 102 , at 96 n.9.

129. 341 F. Supp. 217 (M.D. Ala. 1971), aff'd without op., 405 U.S. 970 (1972).

130. See State v. Taylor, 415 So. $2 d 1043$ (Ala. 1982) (repudiating Forbush as an inaccurate representation of either common law or Alabama state law); see also City Clerk of Lowell, 366 N.E.2d 717; Simmons v. O'Brien, 272 N.W.2d 273 (Neb. 1978); Dunn v. Palermo, 522 S.W.2d 679 (Tenn. 1975); CLARK, supra note 104 (citing cases); MacDougall, supra note 102, at $96 \mathrm{n} .9$ (collecting cases from various states on women's name rights and citing leading cases on 
to light the issue of women's names and prompted litigation that clarified women's naming rights. ${ }^{132}$ As a result of these various cases, it is also well settled that married and divorced women have the right to change their names, statutorily or nonstatutorily, irrespective of what names children in their custody use. ${ }^{133}$ Moreover, it is clear that a woman's use of a particular name does not depend on her husband's or ex-husband's consent. ${ }^{134}$

Cases establishing a woman's right to retain her surname upon marriage revisited nineteenth-century characterizations of the common law upon which regulations restricting women's name choice were based. For example, in Kruzel v. Podell, ${ }^{135}$ the Wisconsin Supreme Court corrected earlier views of the common law on women's names, as enunciated in Chapman v. Phoenix National Bank of New York. ${ }^{136}$ According to the court in Kruzel, the court in Chapman incorrectly characterized the common law on marital names. ${ }^{137}$ Contrary to Chapman, said the court in Kruzel, common law did not compel a woman to assume her husband's name after marriage. ${ }^{138}$

Moreover, later cases disrupted the close relationship between custom and law upon which state-mandated name change was often based. ${ }^{139}$ In a leading case on women's name rights, Dunn v. Palermo, the Tennessee Supreme Court held that a resident registration statute could not be interpreted to mandate a woman's name change upon marriage. ${ }^{140}$ The court rejected the argument that custom should govern law, due to the limitations on women's full participation as citizens such an approach to law would impose. $^{141}$

[M]arried women have labored under a form of societal compulsion and economic coercion which has not been conducive to the assertion of some rights and privileges of citizenship. The application of a rule of custom and its conversion into a rule of law, would stifle and chill virtually all progress in the rapidly expanding field of human liberties. ${ }^{142}$

Underlying the court's reasoning in Dunn is the sense that control over one's name implicates questions of freedom and equality. The question of marital names was no longer just a question of administrative convenience for the state, ${ }^{143}$ or merely one of

married women's right to retain their names upon marriage); Case, supra note 127 (citing cases).

131. Forbush v. Wallace, 405 U.S. 970,970 (1972).

132. MacDougall, supra note 102, at 94.

133. Id. at $96 \mathrm{n} .9$ (citing cases).

134. Id.

135. 226 N.W.2d 458,460 (Wisc. 1975).

136. 85 N.Y. 437 (1881).

137. Kruzel, 226 N.W.2d at 463-64; see also Dunn v. Palermo, 522 S.W.2d 679, 683 (Tenn. 1975) ("Virtually all cases holding that a woman changes her name by marriage are bottomed on a faulty construction of Chapman v. Phoenix National Bank of N.Y., 85 N.Y. 437 (1881).").

138. Kruzel, 226 N.W.2d at 460.

139. See Forbush v. Wallace, 341 F. Supp. 217 (M.D. Ala. 1971), aff'd without op., 405 U.S. 970 (1972) (per curiam).

140. See Dunn, 522 S.W.2d at $681,688-89$.

141. See id. at 688 .

142. Id.

143. See Forbush, 341 F. Supp. at 222 ("[The] cost of a change to the State of Alabama far 
trivial social practice, but a matter of consequence on a par with the "societal compulsion and economic coercion" that married women had historically endured. ${ }^{144}$ Names, in the Dunn court's view, bore significant social meaning as a very public site of women's equality and freedom.

As I will discuss in the next Part, the formal legal recognition of women's right to control their names has pushed the issue of marital naming into the "private" domain, divesting it of the public, substantive significance it once bore during the first and second waves of feminism.

\section{B. The Private Choice of Marital Naming}

To the extent that the law now formally recognizes women's right to control their names, the marital-names question is generally perceived as an issue of private, individual choice. The battle over women's names appears to be over and done. Or is it? I argue here that the consignment of marital names to the domain of private choice is based on a flawed assumption of the "choice" that governs marital names. In this way, marital-names practices, even in our current formally free regime, raise similar concerns as same-sex marriage about constraints on individuals' abilities to control language and, therefore, their status.

The postfeminist view of marital names presupposes that this is an area no longer constrained by the state or other external forces that might otherwise maintain the status of marital names as an issue of public import. Women are now presumed to be free, like men, to do what they want with their names. This appears to contrast with the constraints placed on same-sex couples in the same-sex marriage context, in which the state actively controls the public vocabulary of social recognition of equality. I argue, however, that the putative choice that distinguishes the private choice of marital names from the public-regarding nature of same-sex marriage is complicated at best. Choice is constrained in the marital-names context in ways that we have collectively overlooked.

\section{The Immunity of Choice}

While same-sex marriage is generally constructed as a setting in which individuals do not have the choice to opt into the public language of social recognition of equality, marital names are generally viewed as a nonissue from a status standpoint because women appear to have "choice"- to keep, change, hyphenate, or do something entirely different, such as make up a new name with their spouse. This appearance of choice immunizes the results of this exercise of "choice" from substantive, status-focused scrutiny.

Feminist legal theorists have identified the ways in which the illusion of individual choice itself masks the social forces that impede the exercise of that choice. For example, in the employment discrimination setting, Tracy Higgins has criticized Title VII's $^{145}$ failure to address fully gender-based job discrimination, wherein women are

outweigh[s] the harm caused the plaintiff....").

144. Dunn, 522 S.W.2d at 688.

145. 42 U.S.C. $\S 2000$ e to e -17 (2006). 
encouraged to participate in the workforce in areas primarily considered "traditional women's work," and women earn less money than men. ${ }^{146}$

Higgins contends that Title VII has failed to close gender-based gaps in the workplace because society sees these disparities as "a product of individual choice rather than workplace bias." ${ }^{147}$ The assumption that any gender-based differences result from individual choice appears to absolve Title VII of any responsibility to supply remedies for those differences. ${ }^{148}$

For example, Higgins argues that while overtime requirements disparately affect women, when childcare is taken into account, Title VII does not insist on accommodations because parents are presumed to make individual choices regarding division of labor. ${ }^{149}$ This assumption that choice dictates this allocation of duties persists, regardless of the fact that women predominantly bear the burden of childrearing in our society. ${ }^{150}$

Higgins's critique highlights the function that the appearance of choice serves in the marital-names context. It renders marital names entirely a matter of private, individual choice that exists separate and apart from any structural constraints, both within and outside of the family. Choice in the naming context, therefore, helps construct the decisional playing field as a level space in which all actors are alike and equal. As I discuss in the next Part, women's choices in marital names are most appropriately described as demonstrating "partial agency," at best.

\section{Partial Agency}

The assumption that the formal recognition that women have a right to control their names means that women act entirely freely with regard to their names is misguided. Although women certainly do enjoy substantially greater legal rights - and to some extent, greater social rights-regarding their names than they certainly did fifty or one hundred years ago, this freedom is partial at best. The concept of partial agency that feminist legal theorists and queer theorists have offered in the context of sexuality provides a useful framework for understanding constraints imbedded in the maritalnames context.

Kathryn Abrams, writing in feminist legal theory, has advanced a theory of women's "partial agency" in an effort to chart a course between the perceived pitfalls of traditional liberal theory's embrace of agency and dominance feminism's rejection of it. In the context of sexuality, Abrams has criticized traditional liberal theory for its tendency to "mute the differences in power or social circumstances" that might constrain agency. ${ }^{151}$ She has also observed the tendency of dominance feminism, in the context of sexuality, to "characteriz[e] women as pervasively constructed by male

146. Tracy E. Higgins, Job Segregation, Gender Blindness, and Employee Agency, $55 \mathrm{ME}$.

L. REv. 241, 243 (2002).

147. Id.

148. Id. at 246 .

149. Id. at 249 .

150. Id. at 248 .

151. Kathryn Abrams, Sex Wars Redux: Agency and Coercion in Feminist Legal Theory, 95 CoLuM. L. REV. 304, 305-07 (1995). 
aggression," thereby precluding the possibility of developing a positive theory of women's sexuality. ${ }^{152}$

Abrams looks to sexuality as a context in which the drawbacks of both traditional liberalism and dominance feminism emerge most saliently. The notion of "partial agency" attempts to take into account women's agency as well as the constraints on that agency. As partial agents, women are "neither wholly empowered nor wholly incapacitated." 153

The notion of "partial agency" provides a useful framework for understanding marital-name practices and women's control in this context. In evaluating whether and how much choice women have over their names, we must take into account the context in which that choice is exercised. This is necessary because choice itself arises amidst social forces that shape our understandings of what is a choice and what is not.

\section{Baselines and Construction of Choice}

While Abrams sets out the possibility that women can be both empowered and constrained at the same time, other feminist and queer theorists have elaborated on the nature of constraints on agency, contending that our understandings of choice depend on the normative baselines from which we base our evaluations of choice.

Katherine Franke, for example, has critiqued the social construction of the concept of choice in the context of female sexuality, arguing that our understandings of who is exercising choice when it comes to reproduction depend on what I refer to herein as socially constructed baselines. ${ }^{154}$ Franke criticizes legal feminism's "repronormativity," arguing that legal feminism accepts without question the assumption that most women become mothers without questioning the social forces that urge women to reproduce. ${ }^{155}$ She argues that reproduction has been taken for granted to such an extent that only women who are not parents are regarded as having made a "choice," one that is "constructed as nontraditional, nonconventional, and for some, non-natural."156

Franke's critique of the constructed and contingent nature of choice, predicated on normative baselines, informs our understanding of the choices presumed to be exercised in the names context. Marital-name practices operate against baselines that shape our understanding of choice. Decisions about names do not arise against a blank slate of equal options, but operate within the confines of social forces that construct our options and our understanding of those options. In other words, women's name change operates within the structure of gender hierarchy that initially limits the options from which women are able to choose.

This is most evident when we examine the interplay between gender and the reasons offered for women's name change. Leading expressive rationales offered for women's name change include the desire to communicate marital union and commitment, ${ }^{157}$

152. Id. at 304 .

153. Id. at 362 .

154. Katherine M. Franke, Theorizing Yes: An Essay on Feminism, Law, and Desire, 101

Colum. L. ReV. 181, 181 (2001).

155. Id.

156. Id. at 185 .

157. Diana Boxer \& Elena Gritsenko, Women and Surnames Across Cultures: Reconstructing Identity in Marriage, WOMEN AND LANGUAGE, Fall 2005, at 1. 
family connection and solidarity, ${ }^{158}$ the start of a new life, ${ }^{159}$ and the beginning of new family. ${ }^{160} \mathrm{~A}$ leading pragmatic rationale offered for women's name change is the desire to avoid the confusion of having a different last name from one's children. ${ }^{161}$

Although each of these reasons is sensible, none accounts for the demographic picture of name change we have today, in which most women change their names, and most men do not. To the extent that a shared name represents union, commitment, family connection, a fresh start, and a new family, these messages can theoretically be achieved by sharing the wife's name, rather than the husband's. But this is not how marital name change occurs.

Social science tells us that name change is generally viewed as the domain of women in marriage, not of men. For example, name change by the woman is seen as a way for women to show commitment to their husbands-" "[i]t shows commitment on my part and that is why I got married-to commit myself to my husband."162 Another woman in a 2005 survey by linguists Diana Boxer and Elena Gritsenko said, "My husband and I do most things together and we are officially a team and a union with the same name. I, personally, wouldn't want to be married unless I took my husband's name. Marriage is a commitment, and I feel more committed by using his name."163

158. Id. at 3. The expressivism of name change as a sign of marital status and family unity has its corollary in other societies undergoing change in family structures. Until 1917, Russian women were required to take their husbands' names and to keep the name even through the dissolution of the marriage. Id. at 4. Later, under the Soviet Union, both men and women were given a choice about whether to keep their names or take on their spouses', however, hyphenated names were not an option. Id. Although today women in Russia have the choice of keeping their maiden names, taking their husbands' names, or hyphenating, choices are generally "governed more by the "law of tradition,"' and many women seem to feel a moral obligation to change their names. Id. at 4-5. In fact, unlike English, which applies the term married to both male and female, Russian labels the married woman zamuzhem, derived from the word "husband" and connoting dependence. Id. at 5. Zhenat, on the other hand, the term for a married man, derived from the word for "wife" but lacks any implied dependence. Id.; cf. Sally McConnell-Ginet, "What's in a Name?" Social Labeling and Gender Practices, in THE HANDBOOK OF GENDER AND LANGUAGE 69, 86 (Janet Holmes \& Miriam Meyerhoff eds., 2003) (discussing Japanese practice of using second-person pronouns or affixes to denote familial relationships).

I have found no studies looking specifically into race-based name practices in the United States, but the Massachusetts study by Goldin and Shim made some interesting findings. They found that in the late 1990s, African-American married women were almost twice as likely to be name keepers than white women, and the fraction keeping their names was about the same, regardless of whether the subjects had obtained a college degree. This contrasts starkly with the data for white women, for whom college education was a major determinant of name change or keeping. Goldin \& Shim, supra note 4, at 152.

159. Susan L. Kline, Laura Stafford \& Jill C. Miklosovic, Women's Surnames: Decisions, Interpretations and Associations with Relational Qualities, 13 J. SOC. PERS. RELATIONSHIPS 593, 610 (1996).

160. Boxer \& Gritsenko, supra note 157 , at 3.

161. Id.

162. Karen A. Foss \& Belle A. Edson, What's in a Name? Accounts of Married Women's Name Choices, 53 W. J. SPEECH COMM. 356, 360 (1989).

163. Boxer \& Gritsenko, supra note 157, at 3. 
Women's own accounts of name change in opposite-sex marriages reveal that gender deeply influences the social baseline for name change, one in which name change is a practice for women to do. When name change is viewed as the province of women, rationales offered for name change may make a great deal of sense, but not once we take name change out of a gender framework. They do not explain why we do not have a more equal mix of men and women changing and keeping their names.

Undoubtedly, naming practices arise from a variety of factors beyond gender. Ethnic solidarity or a desire for privacy may motivate women in interracial or interfaith couples either to take or keep their husbands' last names, based on the information that names communicate. While gender may not explicitly motivate naming decisions, gender does tend to determine who navigates their way through this complex array of factors-namely, women.

A similar baseline problem arises in the departure of mothers from the workforce when they have children. In recent years, the popular press has reported on a trend of professional women "opting out" of the workforce to stay home with their children. ${ }^{164}$ The characterization of this movement out of the workforce presupposes that these women are acting entirely freely, with the choice to "opt in" or "opt out."

Within this framework of choice, staying home with children looks like an equal option to continuing to work when women are faced with the demands of balancing work life and family life. The normative baseline that operates here is one in which women are primary caregivers to their children and workplaces do not generally accommodate the caregiving responsibilities of their employees.

This view of women's migration out of the workforce as a case of "opting out" fails to take into account the extent to which women's choices are constrained at the outset by structural patterns both within the home and the workplace. Like name change, opting out looks like a choice when viewed from a particular socially constructed baseline. In the case of opting out, that baseline is that only women care for children and that workplaces and family do not mix. In the case of marital names, it is that only women change their names, not men.

\section{Troubled Choice in Marital Names}

Within a narrowed decisional framework in which only women change their names, women's choices occur amidst a host of legal and social constraints. The persistence of married couples continuing a gendered social practice that is no longer explicitly enforced by the law suggests a lag between the formal law and everyday social practice. What accounts for this discrepancy between law and everyday reality?

Although women formally enjoy legal control over their names, they are still constrained in both residual legal and social ways. First, the view of women's name change as the norm residually affects legal rules on names. Second, the view of women's name change as the norm further reinforces this social practice.

The persistence of same-race marriage provides a useful framework for understanding the dynamics at play in the continued practice of women taking their

164. See, e.g., Belkin, supra note 100, at 42; Story, supra note 100, at A1; Claudia Wallis, The Case for Staying Home, TrME, Mar. 22, 2004, at 50. 
husbands' names. Rachel Moran has observed that although Loving v. Virginia ${ }^{165}$ removed formal barriers to interracial marriage, same-race marriage is still predominantly the norm. ${ }^{166}$ In reconciling the "[c]olorblind [i]deal" of Loving with the "[p]ersistence of [h]igh [r] ates of [s]ame-[r] ace [m]arriage," ${ }^{167}$ Moran has argued that the emphasis placed on "romantic individualism"168 has "[s]ubmerged"169 race as a factor in the complex process of finding and falling in love with a mate. ${ }^{170}$ "The rise of romanticism permits individuals to rely on love to explain their marital choices without ever thinking very hard about the characteristics that make their partners lovable." ${ }^{171}$

While a choice like selecting one's mate might look like an individual act, Moran argues, this decision is "not entirely individual because romantic preferences are highly contextualized." 172 Furthermore, "[w]hile love itself may seem like an irrational impulse, that most intimate of feelings is a product of social forces that transcend the individual. For love to be intelligible, it must occur within accepted cultural parameters." $" 173$ For example, Moran observes the extent to which racial segregation has produced "disparate social and cultural practices" that play a role in mate selection motivated by cultural affinity. ${ }^{174}$

Moran's analysis of same-race marriage post-Loving is instructive in the context of marital names because it underscores the extent to which assumptions about the extent of individual choice to act in ways that follow the status quo can be flawed. Her examination of the "highly contextualized" nature of individual choice, even in matters as seemingly individual as marriage, highlights both the legal and the social factors that can constrain choice in marital names.

In this Part, I discuss the legal and social factors that influence women's choices regarding their names, despite formal gender neutrality.

\section{a. Legal Constraints}

To the extent that the perception of marital names as the domain of individual choice is based on changes in the law, some recent family law scholarship suggests that

165. 388 U.S. 1 (1966).

166. RACHEL MORAN, INTERRACIAL INTIMACY: THE REGULATION OF RACE AND ROMANCE 6 (2001). According to the 2000 census, over $96 \%$ of whites marty a same-race spouse, while over $90 \%$ of blacks, $90 \%$ of Asians, $80 \%$ of Hispanics or Latinos, and $45 \%$ of Native Americans marry a spouse of the same race. U.S. Census Bureau, Hispanic Origin and Race of Wife and Husband in Married-Couple Households for the United States: 2000 (Mar. 13, 2003), http://www.census.gov/population/www/cen2000/briefs/phc-t19/tables/tab01.pdf. These percentages were only slightly lower for unmarried partners in every category. U.S. Census Bureau, Hispanic Origin and Race of Opposite-Sex Unmarried Partner Households for the United States: 2000, (Mar. 13, 2003), http://www.census.gov/population/www/cen2000/ briefs/phc-t19/tables/tab02.pdf.

167. MORAN, supra note 166, at 111.

168. Id. at 125.

169. Id. at 116.

170. Id at 125 .

171. Id. at 116 .

172. Id. at 125.

173. Id.

174. Id. 
despite the formal recognition of choice, the law still residually constrains naming choices.

Although the legal framework for marital names today is formally gender-neutral, Elizabeth Emens has suggested that the law still reflects traditional social norms on name change. For example, Emens has found that it is more difficult in many states for husbands to change their names to their wives' than the other way around. Husbands' name change in these jurisdictions often requires the added step of a formal court order, which is not required to effectuate a wife's name change. ${ }^{175}$ To the extent that the law makes it more difficult for men to take their wives' names than for wives to take their husbands' names, the law limits women's choices on name change by limiting men's choices.

In addition, the law has been found to constrain couples who seek to break away from the tradition of changing from one spouse's name to the other's. For example, Emens has discovered that many jurisdictions require the additional administrative step of procuring a court order for a couple to adopt a new name. ${ }^{176}$ This added burden makes it harder for married couples to do anything other than follow the pattern of women taking their husbands' names.

Emens has found that constraints on choice arise in less formal legal contexts, including in what she calls "desk clerk law." ${ }^{177}$ Emens argues that states and localities informally place burdens on choice through federal, state, and local desk clerks giving "inaccurate, incomplete, contradictory, or normative responses to specific questions about legal options." 178 Social attitudes about name change continue to inform the law insofar as desk clerks often give normatively driven responses to questions about name change that lead questioners to have to undertake more burdensome measures-like going to court-when trying to pursue anything other than the traditional pattern of women taking men's names. ${ }^{179}$

These residual legal constraints suggest that social practice still shapes legal norms, echoing the historically mutually reinforcing relationship between custom and law in the area of marital names. ${ }^{180}$

\section{b. Social Constraints}

Although the law may formally confer freedom on women to choose what to do with their names, social norms about naming influence the exercise of that choice. The persistence of name change normalizes it to the extent that individuals experience social costs and benefits from breaking with or following prevalent social practice. These social costs and benefits together influence women's choices.

Social benefits from women's continued name change include the security of following tradition. Women in studies on marital naming point to the desire to follow tradition as a justification for adopting traditional name practice. "Custom,"

175. Emens, supra note 96 , at 822-23. Emens documents how some states place additional administrative burdens on unconventional marital name changes. Id.

176. Id. at 822 .

177. Id. at 823-27.

178. Id. at 824 .

179. Id.

180. See supra Part IV.A for a discussion of the legal framework of marital naming. 
"convention," and "tradition" are common explanations for name changes. ${ }^{181}$ Many describe name change as "the thing to do," or "a conventional practice." 182 Others say they "never considered doing anything else." " 83 These accounts confirm that custom begets custom. ${ }^{184}$

An additional social benefit influencing women's name change is the satisfaction of one's husband or family. Studies show that familial and spousal expectations also motivate women's name changes. ${ }^{185}$ Some women who change their names do so in compliance with their husbands' wishes. ${ }^{186}$ These women say, “[m]y husband asked me if I would change my name. . . He said he really wanted me to take his name because of tradition and the fact that it meant so much to him. He said if I loved him I would want to change my name." 187 Many women report that their husbands would have viewed their wives' decision not to take their names as a "rejection." 188

In some cases, men's name preferences for their wives may be related to widely held personal views on names. For example, in their study on college students' attitudes about marital-name practices, sociologists Laurie Scheuble and David Johnson found that males were more likely than females to believe that a woman should take her husband's last name when she marries if her relatives think she should, and to believe that women should always change their last names to that of their

181. See supra Part IV.A for a discussion of the legal framework of marital naming.

182. Foss \& Edson, supra note 162, at 361; see supra Part IV.A for a discussion of the legal framework of marital naming.

183. Foss \& Edson, supra note 162 , at 361 ; see supra Part IV.A for a discussion of the legal framework of marital naming. Studies conducted in the 1990s have shown that traditionalism and gender-role traditionalism are factors for those who change their names. Johnson \& Scheuble, Naming in Two Generations, supra note 82, at 724; Kline et al., supra note 159, at 610. In a 1996 study aimed at uncovering the issues considered by women when making a decision about their marital name, traditional name changers were found to hold an ideological orientation toward traditionalism and traditional gender-role expectations and saw changing their surnames as a traditional part of marriage. Kline et al., supra note 159, at 610 . David R. Johnson and Laurie Scheuble found in a national study of women's marital naming that gender role traditionalism is a major determinant of naming choices. Johnson \& Scheuble, Naming in Two Generations, supra note 82 , at 727 . Relatedly, family history plays a part in naming choices. Johnson and Scheuble found that the marital-naming choice had a strong effect on a daughter's naming, but interestingly, no effect on the name used by her son's spouse. Id.

184. While tradition-based rationales have been less popular since the 1970 s, some evidence suggests that appeals to tradition are making a comeback. In a 2004 study, Elizabeth Suter found that women married prior to the 1970s often changed their name because of tradition, or in other words, because that is what they "should" do. Suter, supra note 82, at 69. Women married in the 1970s and early 1980s, however, did not tend to use tradition as a factor when making their name-change choices, considering instead factors like personal choice, identity issues, and reactions to administrative realities. Id. at 72 . Women married in the 1990 s were divided between those who appealed to tradition and those who perceived themselves as having more choices than their mothers. Id. at 75 . They did, however, appeal to tradition more than their counterparts married in the 1970s and 1980s. Id.

185. See Boxer \& Gritsenko, supra note 157, at 3.

186. Foss \& Edson, supra note 162, at 361 .

187. Id. (alteration in original).

188. Id. 
husbands. ${ }^{189}$ Males were also more likely than females to believe that a man should never change his last name to his wife's. ${ }^{190}$

An additional factor in women's naming decisions is the desire to be seen as a gender-conforming "team player." Studies show that naming practices affect perceptions of women. Women who take their husband's names are perceived as more "communal" than women who either kept their birth names or hyphenated their names. ${ }^{191}$ The main stereotypes associated with a woman who maintains her birth name at marriage are "assertiveness," "orientation towards a job," and "urban upbringing." 192

Even women who choose to hyphenate face social perceptions they might find too costly. ${ }^{193}$ Men and women generally perceive women with hyphenated names as career oriented and bearing a more androgynous gender role and gender identity. ${ }^{194}$ Conversely, men with hyphenated names are perceived as "highly committed" to the marriage. ${ }^{195}$

To the extent that couples seek to have a shared name for the expressive value name sharing holds, women's choices are necessarily affected by the social constraints on men's ability to take their wives' names. Social expectations about name change residually affect informal desk clerk law on name change, as discussed above. ${ }^{196}$

The social costs for men taking their wives' names include the perception of being nongender conforming and implicitly "unmasculine." Confirmation of this social cost is reflected in the following comment in a recent issue of the Yale Alumni Magazine about a graduate of the class of 1997 who took his wife's name: "So Mr. Robbins [his wife's name], congratulations. You are brave. You are progressive. You are probably mocked by other men." 197

An additional social factor affecting women's choice is the social custom of children receiving their father's surname, regardless of the mother's name choice. A

189. Scheuble \& Johnson, College Students, supra note 82, at 751.

190. Id.

191. Claire E. Etaugh \& Judith S. Bridges, "Names Can Never Hurt Me?" The Effects of Surname Use on Perceptions of Married Women, 23 PSYCHOL. WOMENQ. 819 (1999) (sampling 222 female and male students at a private university and rating impressions of three thirty-twoyear-old women who (1) took husband's name, (2) kept birth name, (3) used hyphenated name).

192. Sheila M. Embelton \& Ruth King, Attitudes Towards Maiden Name Retention, OnOMASTICA CaNADIANA, Dec. 1984, at 11, 18.

193. Of the ten percent of American women who do not adopt their husband's name upon marriage, five percent hyphenate their last name with their husband's. Suter, supra note 82, at 58. According to social science studies on name practices, name hyphenators tend to do so in order to maintain their sense of self, in the manner of name keepers, in addition to acknowledging their ties to their new families, in the manner of name changers. Kline et al., supra note 159 , at 610 .

194. Gordon B. Forbes, Leah E. Adams-Curtis, Kay B. White \& Nicole R. Hamm, Perceptions of Married Women and Married Men with Hyphenated Surnames, 46 SEX ROLES 167, 172-73 (2002).

195. Id. at 173 . These studies contrast with a 1991 sociology study by Kathleen McKinney which found that choice of a woman's last name did not affect how respondents viewed a married woman. Kathleen McKinney, The Influence of Choice of Last Name and Career Status on Perceptions of a Woman and Her Spouse, 19 FREE INQUIRY CREATIVE SOC. 1, 6 (1991).

196. Emens, supra note 96 , at 765; see also supra notes $175-76$ and accompanying text.

197. Class Notes 1997, Yale AlumN MAG.122, July/Aug. 2008, at 122. 
strong tradition exists by which children are given their father's name. ${ }^{198}$ Even children of women who keep or hyphenate their names usually bear their father's name. ${ }^{199}$

The norm of children receiving their father's last name imposes costs on women who choose to keep their names and confers benefits to those who change their names. For example, women explain their decision to take their husband's name as a way to shield their children from messages associated with name retention and to promote the messages of name change. A major reason offered for name change was to protect children from "confusion" because women's name change "is simpler for the children." 200

Social science accounts show that the confusion sought to be avoided is based on the perceptions of others. According to one mother, "[ $[\mathrm{t}] \mathrm{he}$ children would not have to feel odd or different from their peers and explain why their parents have different names or be teased about an uncommon situation." 201 A mother in another survey said that having a different last name from her children "smacked of illegitimacy."202

Beyond the social messages of a mother bearing a different name than her children, social norms about name change further influence women's decisions about their names because these norms affect the practical realities of daily life. Women refer to the administrative confusion that can result from mothers not changing their last names. In one study, a married woman in her thirties explained, "[w]e plan on having children and I have seen, firsthand, how confusing it can be for schools and doctors' offices to keep straight hyphenated last names, or children with last names that are different than the parent's name."203

A final social influence on women's name change is a "hedonic" narrative of women's name change. This narrative recounts the joy, pride, romance, or other pleasure associated with name change. The postfeminist writer Katie Roiphe describes the sensations and emotions associated with name change: "There's something romantic and pleasantly old-fashioned about giving up your name, a kind of frisson in

198. See M.D. v. A.S.L., 646 A.2d 543, 544 (N.J. Super. Ct. Ch. Div. 1994) (“In modern society, it has been customary for a child to assume the surname of the father ...."); Rio v. Rio, 504 N.Y.S.2d 959, 960-61 (Sup. Ct. 1986) ("Most American children born in wedlock are given their father's surname," and this is a "practically universal custom." (citation omitted)); Kay v. Bell, 121 N.E.2d 206, 208 (Ohio Ct. App. 1953) ("It has been the custom in our country since the time 'when the memory of man runneth not to the contrary' to give to a child the surname of its father." (citations omitted)); see also Merle H. Weiner, "We are Family": Valuing Associationalism in Disputes over Children's Surnames, 75 N.C. L. REV. 1625, 1637 n.50 (1997).

Legal standards for disputes regarding name change of children's surnames are heavily controlled by the father. MacDougall, supra note 102, at 131 ("[C]hildren's names ... remain almost completely subject to paternal control."); Weiner, supra, at 1630 (citing MacDougall, supra note 102, at 131)). There is a "nearly absolute presumption in favor of the paternal surname." Beverly S. Seng, Note, Like Father, Like Child: The Rights of Parents in Their Children's Surnames, 70 VA. L. REV. 1303, 1305 (1984).

199. Emens, supra note 96, at 791-92.

200. Foss \& Edson, supra note 162 , at 361 .

201. Id.

202. Id.

203. Boxer \& Gritsenko, supra note 157 , at 3. 
seeing yourself as Mrs. John Doe in the calligraphy of a wedding invitation on occasion." 204

The notion of marriage as a new beginning and a special institution often grounds the positive feelings associated with name change. These feelings often include pleasure and excitement, as confirmed by a woman in one study who explained, "I felt very pleased and sort of excited as I was starting in the first leg of a new experience." 205 Another woman in the same study said, "[m]y boss called me Mrs. a couple of weeks after I was married and it made me feel very good. I felt part of something special.",206

Descriptions of the pleasant feelings associated with name change reveal the view of marriage as one based on union with one's husband. A woman in one study said, "I like being identified in a concrete way with him."207 Another said, "I am honored to share his name." 208

While these feelings may not necessarily be the principal motivation for an individual woman's name change, the narrative of pleasure associated with women's name change can exert a powerful influence on naming decisions.

Cultural justifications for naming practices are important areas for consideration. Social science reflects the common sense observation that naming practices are motivated by a wide variety of social and cultural factors. Cultural explanations for name change do not, however, render this social practice immune from a hierarchybased critique. The human rights setting, which often witnesses the clash between human rights and culture, is instructive. ${ }^{209}$ In both settings, culture-based rationales do not, and should not, obviate our rigorous examination of social practices that mark and perpetuate hierarchy based on gender.

\section{Marital Naming as Gendered}

Apart from whether women's name change arises through unfettered choice, the practice itself is worthy of substantive consideration. The state's recognition of women's equality through a formally equal approach to names does not mean practices concerning names do not still affect status. The seemingly trivial nature of language practices makes it easy for us to overlook ways in which we perpetuate hierarchy through our continued participation in social practices that reproduce a legally set

204. Roiphe, supra note 95.

205. Foss \& Edson, supra note 162 , at 362.

206. Id.

207. Id. at 360 .

208. Id. at 361 .

209. Human rights critiques of the cultural practice of female genital mutilation serve as one example of concerns over human rights prevailing over the assertion of cultural rights. See Catherine L. Annas, Irreversible Error: The Power and Prejudice of Female Genital Mutilation, 12 J. CONTEMP. HEALTH L. \& POL'Y 325, 331 (1996) (criticizing the use of "tradition" to justify female circumcision by analogizing the practice to the "pernicious 'tradition"" of slavery); Khadijah F. Sharif, Female Genital Mutilation: What Does the New Federal Law Really Mean?, 24 FORDHAM URB. L.J. 409, 422-423 (1997) (discussing the Immigrant Responsibility Act, which outlaws the ritual in the United States, and arguing that "cultural defenses are not recognized as legitimate reasons for performing the ritual"). 
status quo. I argue in this Part that our unexamined continuation of this language practice reflects and reinforces gender hierarchy both within and outside of marriage.

\section{Reflecting Gender Hierarchy}

The prevalence of women's name change today reflects gender hierarchy both inside and outside of marriage in several ways. First, as widely explored by others, it serves as a remnant of the overtly patriarchal, coverture-based structure of marriage in which a wife's identity was subsumed under that of her husband's. Second, it reflects the extent to which a woman's social status is determined to a great degree by her marital status, and accordingly, her affiliation with men. Third, it reflects the extent to which women's claims to privilege are often predicated on women's similarity to men. I address each of these aspects in turn.

The widespread continuation of women's name change reflects the patriarchal history of marriage in starkly literal terms. As discussed previously, the doctrine of coverture rendered a wife legally invisible. ${ }^{210}$ Women's automatic adoption of their husbands' names has historically reflected women's civilly dead status and reinforced it. While the legal and social status of women and wives has radically improved both within marriage and without, the wholesale maintenance of a practice rooted in patriarchy risks tethering us too closely to the gender-discriminating aspects of marriage as it has functioned historically.

Social science and everyday observation tell us that women's name changes are attributable to at least the appearance of choice, if not the outright exercise of it. Most women and men today would never claim a desire to support a patriarchal conception of marriage through women's name change, but an apparent absence of discrimination in the process of naming decisions does not alleviate concerns about the discriminatory outcomes in naming practice. ${ }^{211}$

In the same-sex marriage context, differential language practice-_"marriage" versus "civil union"-is assumed to be discriminatory because it suggests that same-sex couples (and the lesbian and gay individuals within those couples) are being treated unequally relative to opposite-sex couples (and the straight people within those couples).

Similarly, language differences in the marital-names context, demonstrated by the fact that women almost always bear their husbands' last names but men almost never bear their wives' last names, reflect a sense of inequality between women and men. The continuation of a historical practice explicitly issuing from and supporting marriage's

210. See supra Part IV.A.3.a for a discussion of coverture.

211. There is some evidence to suggest that women who change their names (at least those interviewed in the late 1980s) did so in part out of a sense that their husbands possessed higher status than they themselves did. In their 1989 study, Foss and Edson found that some women who changed their names expressed a perception of their husbands' relative higher status explicitly and implicitly, saying that their husbands offered "protection," describing their own "dependency" as wives, and describing their husbands as "head of the household." Foss \& Edson, supra note 162, at 360-61. Among these respondents, sharing a name with their husbands is a privilege, with respondents explaining, "I have the name of a man whom I like and respect" and "I am honored to share his name." Id. 
patriarchal structure deserves at least careful scrutiny to the extent that it reflects the vestiges of gender hierarchy in marriage today.

Although the intent behind women's name change today may not be to pay homage to name changing's coverture-based heritage, the widespread persistence of this practice reflects gender hierarchy insofar as it displays through language the extent to which women's social identity is contingent on marriage, and accordingly, their affiliation with men.

Feminist family law scholars, like Laura Rosenbury, have criticized the privileging of marriage within the construction of family law for the way in which the high premium placed on marriage within family law stigmatizes and marginalizes those who live outside marriage's borders. ${ }^{212}$ Rosenbury's critique builds on the work of others writing outside family law like Rachel Moran, who has examined the ways in which white middle-class women in the United States "have traditionally experienced extreme pressure to marry, given their economic and political subordination and the widely held view that '[m]arital status defined women's worth.",213

Last names have not been the only mechanism displaying the traditional dependency of women's social status on their affiliation with men. In addition to surname change, women have traditionally used their husbands' first names as well. Until the late 1960s, American etiquette guides stated that, upon marriage, a woman was to use her husband's first and last names. For example, according to Emily Post's popular etiquette guide, a wife's calling card "must of course be the duplicate of [her husband's], and not read Mrs. J. Hunter Smith when his reads Mr. John J. Smith."214 Widows showed their affiliation with their deceased husbands by bearing both his first and last names. ${ }^{215}$ Throughout history and even today, men have never been advised to use their wives' first names.

Such a suggestion would be viewed as incongruous, given the fact that only a woman's social title (i.e., "Miss" to "Mrs."), a not man's, traditionally changes upon marriage--another linguistic sign of women's social status shifting upon affiliation with men. The introduction of the title "Ms." to apply to single and married women alike was an effort to challenge the social practice of categorizing women based on their relationship to men. But as with the practice of calling women by their husbands'

212. See Laura A. Rosenbury, Friends with Benefits?, 106 MICH. L. REv. 189 (2007).

213. Id. at 213 (quoting Rachel F. Moran, How Second-Wave Feminism Forgot the Single Woman, 33 HOFSTRA L. REV. 223, 229-30 (2004) (alteration in original)).

214. Emily Post, EtiQuette: The Blue Book of Social Usage 110 (1940); Elizabeth L. POST, EMILY Post's ETIQUETTE 459 (1965); see also ANN R. FREE, SocLaL USAGE: A GUIDE TO GOOD MANNERS 153 (1969) (describing, under the "Name Cards" section, a married couple's name card as reading only "Mr. and Mrs. William Howard Barnes, Jr."). Emily Post's etiquette series began acknowledging in its 1969 edition that a woman retains her first name, although she adopts her husband's last name. See ElIZABETH L. Post, EMILY POST's ETIQUETTE 20 (1969) ("A woman's legal name consists of her given name, her maiden name, and her husband's name.").

215. See Emily Post, Etiquette: "The Blue Book of Social Usage" 72 (1945) ("A widow, therefore, should always continue to use her husband's Christian names. She is Mrs. John Hunter Titherington Smith . . . but never Mrs. Sarah Smith, if she cares at all about good taste." (emphasis in original)). 
first names, tradition died hard, with even the major media institution The New York Times refusing to use the term "Ms." until $1986^{216}$

Practices concerning social titles and first names are consistent with the vast disparity between men's and women's surname change upon marriage. These language practices together reflect gender hierarchy insofar as women's social positioning is constructed as contingent on their marital status, and by implication their affiliation with men.

Lastly, traditional name-change practices reflect the extent to which women's claims to social and legal privilege are often times based on women's ability to prove themselves to be less like women and more like men. This emerges most saliently in the observed disparities in name change based on women's professional and educational status.

As discussed previously, social science data show that women who marry later in life, who are better educated, and who are more career-oriented, are generally more likely to observe a name practice other than taking their husbands' last names. ${ }^{217}$ Elaborating on these findings, another study on name practices from 1966 to 1996 found that in the $1980 \mathrm{~s}$ and $1990 \mathrm{~s}$, employed women were 1.5 times more likely to choose a nonconventional name than unemployed women, ${ }^{218}$ and women with higher levels of education were almost three times more likely to choose a nonconventional last name. $^{219}$

These disparities are consistent with a longstanding exception to marital name change for actresses and authors. According to Una Stannard's excellent study of

216. See Wendy Atkins-Sayre, The Emergence of 'Ms.' as a Liberatory Title, 28 WOMEN \& LANGUAGE 8, 10 (2005). Awareness of the term increased in the early 1970s. Id. at 10. In 1971, Bella Abzug introduced the "Ms." bill in Congress that forbade the government from utilizing any titles that identified one's marital status. Although the bill was not successful, it "launched debate about the use of titles to define women." Id. The publication of $M s$. magazine was a pivotal moment in the debate. $M s$. magazine was launched as a "one-shot" sample insert in $\mathrm{New}$ York Magazine in December 1971. Ms. Magazine, Her Story: 1971-Present, http://www.msmagazine.com/about; see also, MARY THOM, INSIDE Ms.: 25 YEARS OF THE MAGAZINE AND THE FEMINIST MOVEMENT 1-19 (1997) (describing the birth of the magazine). The preview issue was released in 1972. At the time, "'Ms.' was a risky choice." Id. at 13. The preview issue explained that "Ms." was "being adopted as a standard form of address by women who want to be recognized as individuals, rather than being identified by their relationship with a man." What 's a Ms.?, Ms., Jan. 1972, at 4. However, the New York Times refused to use it and no discussions were held on the matter until 1984 when Geraldine Ferraro was chosen to run for vice president. William Safire wrote an article promoting the term. William Safire, On Language; Goodbye Sex, Hello Gender, N.Y. TIMES, Aug. 5, 1984, at 6-8. Although Time, the Philadelphia Inquirer, and the Denver Post chose to use it, the New York Times did not agree to use the term until 1986. Atkins-Sayre, supra at 11. "The acceptance by the Times hinted at a shift in institutional images of women." Id.

217. Johnson \& Scheuble, Naming in Two Generations, supra note 82, at 727.

218. Scheuble et al., supra note 81 , at 112.

219. Id. As discussed previously, there is some indication that this education- and employment-based disparity may be closing, at least amongst younger brides. See Goldin \& Shim, supra note 4, at 156 (finding that brides in their mid-twenties had a much lower probability of "keeping"-about twelve to fourteen percentage points-relative to brides older than about thirty years in 1991). 
marital naming in the United States, even during the nineteenth century, when coverture governed marriage, actresses and female authors who had cultivated a reputation for themselves often continued to use their given surnames, at least publicly. ${ }^{220}$

While these trends may be viewed as indications of "progress" on women's names, they actually reflect hierarchy in men's and women's claims to privilege quite dramatically. To the extent that names embody identity, ${ }^{221}$ these "exceptions" suggest that a woman's identity is constructed as fluid unless and until a woman has established a reputation beyond merely being a woman. On the other hand, a man's identity is viewed as fixed, regardless of whether a man has proven himself in any other way beyond merely existing as a man.

Exceptions to women's name change are based on an underlying assumption that in order for women to have a rightful claim to their names, they must prove themselves worthy of the privilege of name keeping that men enjoy. Women must do something other than exist as women to justify name keeping. A key way of showing this is through educational and professional accomplishment.

Current and past social exceptions to name change for professionally accomplished women reflect a status paradigm in which women's claims to their names are tied to their similarity to men, or at least to their differences from other women. Catharine MacKinnon's critique of liberal equality doctrine, in which those who are "similarly situated" to a male-constructed standard, applies with equal force in this context. ${ }^{222}$ According to MacKinnon, traditional equal protection doctrine operates within the "sameness rubric," in which "women are measured according to correspondence with man, their equality judged by proximity to his measure."223

Professional and educated women's name keeping on the basis of established reputation operates in a system in which being a woman is not sufficient justification for a claim to a fixed name. Instead, the measure of a woman's claim to her name is being more like a man and less like other women. The challenge that MacKinnon poses to the "sameness rubric" in the equal protection context resonates in the marital-names context. MacKinnon highlights the indignity of this position, when she asks: "Why should one have to be the same as a man to get what a man gets simply because he is one?"224 Or put another way: why can't a woman just be a woman to get what a man gets simply for being a man?

Even though women have made great strides in gaining legal control over their names, the predominance of women's name change upon marriage highlights the ways in which language practices constitute status by reflecting hierarchical relationships within family law institutions and beyond. First, the prevalence of women's name change upon marriage, and the accompanying absence of men's name change upon

220. See StANNARD, supra note 101 , at $45-46$.

221. See, e.g., Barbara Buchanan \& James L. Brunino, Connotative Meaning of Names and Nicknames on Three Dimensions, 85 J. SoC. PsYCHOL. 143 (1971) (discussing the connotations such as masculine or feminine, active or passive, of first names); Paul Plottke, On the Psychology of Proper Names, 5 IndIVIDUAL Psychol. BULL. 106 (1946) (discussing the importance of proper names to individual identity).

222. See Catharine A. MacKnnNon, Toward a Feminist Theory of The State 200 (1989).

223. Id. at $220-21$.

224. Id. at 225 . 
marriage, reflects gender hierarchy by reflecting a patriarchal structure of marriage in which name change played an integral part. Second, name change reflects the allocation of women's social status based on marriage and their affiliation with men in a way that men do not experience. And third, name change reflects a status paradigm in which women's claims to privilege are predicated on their ability to show themselves as something other than "just women." In these ways, language practices in the form of marital names constitute the status of women by reflecting gender hierarchy both within marriage and beyond.

\section{Reinforcing Gender Hierarchy}

In addition to reflecting gender hierarchy, marital-name practices bear on women's status by reinforcing gender hierarchy both within marriage and within society more broadly. This occurs by virtue of the social meaning expressed by the fact that married couples and marital families nearly always bear the name of the husband or father. While the individual reasons for women's adoption of their husbands' names may vary, the ultimate result - that of most American women taking men's names-reinforces gender hierarchy in marriage by communicating the message that men are the head of the household, despite (or perhaps because of) the advances that women have achieved in many sectors of society.

Historical struggles over women's names were not merely focused on securing a woman's right to choose what to do with her name upon marriage, but also on the hierarchy-reinforcing effect of women's name change. Early feminists focused on the message of gender hierarchy sent by this practice. For instance, Elizabeth Cady Stanton framed her challenge to name change in terms of the effects of name change on women and society, even though name change might result from women's choice: "We cannot overestimate the demoralizing effect on woman herself, to say nothing of society at large, for her to consent thus to merge her existence so wholly in that of another."225

The persistence of gender-based marital name change in the face of dramatic advances in women's legal and social status suggests that women's name change is not merely an anomaly in the movement toward gender equality but actually serves a cultural function connected to advances in women's status in other sectors. This function is to promise the security of gender hierarchy in the face of disruptions of that hierarchy.

Scholars in employment law have explored this hierarchy-reinforcing dynamic. In their article on makeup requirements and gender discrimination in the workplace, Carbado, Gulati, and Ramachandran have argued that "makeup and women's entrance into the modern workplace have gone hand-in-hand."226 They contend that

[t]hrough makeup, women could signify not only femininity but also gender difference ... [T] he presence of makeup on the faces of women inscribed their bodies to convey something like the following assurance to employers: "The fact

225. STANNARD, supra note 101 , at 95 .

226. Devon Carbado, G. Mitu Gulati \& Gowri Ramachandran, Makeup and Women at Work 9 (Fla. State Univ., Pub. Law \& Legal Research Paper Series, Paper No. 178, 2006), available at http://papers.ssm.com/sol3/papers.cfm?abstract_id=873881. 
that we are in the same workplace as men, and doing the same work as men, does not mean that we are in fact the same as men."227

The assurances offered by the presence of makeup on women's faces served purposes of "gender palatability or gender comfort" insofar as "[m]akeup signified that gender integration would not mean the disruption of gender hierarchy.",228

The 2008 presidential campaign offers another example of "gender comfort" and "gender palatability" in action. Both Senator John McCain and Governor Sarah Palin went to great lengths to emphasize the masculinity of "the first dude" Todd Palin. 229 For example, when asked why Governor Palin would make a better vice president than Senator Joe Biden, McCain ended his response by referring to Sarah Palin's husband, saying, "[h]er husband's a pretty tough guy, by the way, too." ${ }^{230}$ In her speech accepting the Republican nomination for vice president, Governor Sarah Palin listed the many virtues of her husband:

Todd is a story all by himself. He's a lifelong commercial fisherman and a production operator in the oil fields of Alaska's North Slope, and a proud member of the United Steel Workers' Union. And Todd is a world champion snow machine racer. Throw in his Yup'ik Eskimo ancestry, and it all makes for quite a package. $^{231}$

The emphasis on Todd Palin's toughness acts as a gender comfort strategy, confirming his masculinity in the face of the disruption of gender hierarchy posed by the possibility at the time that Sarah Palin could become the first female vice president.

The continuation of women's name change functions in a manner similar to makeup in the workplace and other gender comfort strategies insofar as continuity in this social practice provides the reassurance that despite advances of women in numerous sectors of society, gender hierarchy is still in place. The labeling of wives and children with men's last names conveys the message that men are the heads of their households, reinforcing through language what has historically been true in law and social custom.

As with makeup, the seemingly trivial nature of language is critical to the operation of "gender comfort," enabling us to overlook the minor ways in which we participate in behaviors that mimic a legally set status quo, even when the law has changed. But the cumulative effect of gender-based marital name change is to reinforce a gender hierarchy in which men act as the heads of households and women's identities turn on their affiliations with men.

227. Id.

228. Id.

229. Randi Kaye, Todd Palin: First Dude or Shadow Governor?, CNN.com, Sept. 9, 2008, http://www.cnn.com/2008/POLITICS/09/19/todd.palin.

230. Abby Margulies, Broadsheet: Your Daily Debate, SALON.Com, Oct. 16, 2008, http://www.salon.com/mwt/broadsheet/feature/2008/10/16/daily_debate.

231. Cameron Brown, Gabriel Dance, Jonathan Ellis, Ben Gerst, Tom Jackson, Magdalena Sharp \& Sarah Wheaton, Sarah Palin's Speech at the Republican National Convention, N.Y. TIMES.COM, Sept. 3, 2008, http://elections.nytimes.com/2008/president/conventions/videos/ 20080903_PALIN_SPEECH.html. 


\section{REDEFINING MARRIAGE THROUGH NAMING}

Traditional naming of marriage and marital naming operate together to reinforce the gender hierarchy of marriage. Naming marriage does so by defining the sex-based outer contours of marriage. Marital naming constitutes gender hierarchy within marriage.

What are the implications of this relationship between language and status in the marriage context? Does it suggest that marriage is inherently gender hierarchical? Does it suggest abandoning the move toward marriage equality and taking a more radical approach to the state protection of intimate relationships that eschews traditional categories like marriage?

These suggestions have been advanced by others, from both feminist and queer standpoints, and I do not retread this ground here. But to the extent we maintain marriage as a family law status category, this discussion suggests ways in which marriage could become more egalitarian, and less gendered, through naming.

The public application of the title "marriage" to same-sex couples clearly refutes the gender-differentiated definition of marriage. And if "marriage" is no longer a status involving only a man and a woman, then the foundation of gender hierarchy within marriage is snaken.

Moreover, the public extension of the label blurs the line between private and public uses of the term "marriage," by signaling that previously private uses of the term marriage among same-sex couples now have real and valid social meaning from a public standpoint. The use of the term "marriage" by same-sex couples in everyday life, then, may eventually become less threatening because it bears the imprimatur of state and social sanction. ${ }^{232}$

The reframing of marriage to include same-sex couples also opens the way to reconsider the internal dynamics of marriage. These include social practices that have come to define marriage, such as marital naming. In the very few cases involving samesex couples' name change, judicial reaction confirms that name change is traditionally regarded as one of the fundamental practices of marriage and that name sharing is considered basic to our conception of family. ${ }^{233}$

The centrality of naming to marriage is demonstrated in a recent action filed by Gay and Lesbian Advocates and Defenders (GLAD) in federal court challenging the federal

232. See, e.g., Bowers v. Shahar, 114 F.3d 1097, 1109 (11th Cir. 1997) (explaining the importance of public perception that the state would be sanctioning same-sex marriage if a woman claiming to be involved in such a marriage was hired as an attorney for the state).

233. See In re Bacharach, 780 A.2d 579, 585 (N.J. Super. Ct. App. Div. 2001) ("Appellant and her partner can exchange rings, proclaim devotion in a public or private ceremony, call their relationship a marriage, use the same surname, adopt and rear children."); In re Daniels, 773 N.Y.S.2d 220, 222 (N.Y. Civ. Ct. 2003) (acknowledging that common surnames can lead to confusion about marital status because names are meant to "reflect familial relationships"); In re Bicknell, 771 N.E.2d 846, 847-49 (Ohio 2002) (accepting same-sex couple's desire for their family to "have a unified name in the eyes of the law" as reason for name change); In re Miller, 824 A.2d 1207, 1213 (Pa. Super. Ct. 2003) (granting name change where the purpose of change was for same-sex couple "to demonstrate their level of commitment to each other and to the children that they planned to have"). 
Defense of Marriage Act (DOMA). ${ }^{234}$ According to the suit's initial complaint, one of the Massachusetts plaintiffs sought to obtain a passport in his "married" name from the State Department. After marrying his partner, the plaintiff took his spouse's last name. Invoking DOMA, the State Department insisted on issuing the passport in the plaintiff's "maiden" name, despite submission of his marriage certificate and other government-issued identification, which the State Department accepts as evidence of name change from opposite-sex married couples. ${ }^{235}$ After the filing of the original complaint, the State Department issued the plaintiff a passport. ${ }^{236}$

Because of the centrality of naming practice to marriage, the rejection of same-sex marriage embodied by DOMA extends to those practices of marriage, like marital naming, that same-sex married couples attempt to pursue. The GLAD case suggests, then, that same-sex marital-naming practices bear the potential to disrupt further the gender-hierarchical roots of marriage. In same-sex marriage, there is no obvious way, based on sex, for couples to navigate their way through marital-naming decisions. Name changing in same-sex marriage therefore holds the promise to proceed from conversation, rather than from gender-based expectation.

The reframing of marriage to include same-sex couples would not necessarily lead to a wholesale overhaul of gendered marital practices. For example, there is some reason to believe that gender would still influence same-sex marital naming. In data that she collected regarding naming practices in Vermont civil unions during the first year that such relationship status was offered, Emens found that of the six percent of couples who shared some part or all of their last names, women disproportionately shared their names compared to men. ${ }^{237}$ Such findings suggest the persistence of gender-based attitudes toward name changing that may be influenced by the gendered social expectations surrounding heterosexual marital naming.

Moreover, marital naming may still be viewed by many same-sex couples as the domain of straights. For example, in a 2008 British psychology study looking at samesex couples' attitudes toward name change, the authors concluded that the laughter accompanying responses to questions about name change "confirmed [their] suspicions that name practices are of little importance for many non-heterosexuals." ${ }^{238}$ Indeed, some same-sex couples look to name keeping as a way to resist "heteronormativity."239

There are some, however, who view naming practices as a means of showing family connection, rather than heteronormativity. Same-sex marital naming promises an

234. 1 U.S.C. $\S 7$ (2006); 28 U.S.C. $\S 1738 C$ (2006).

235. Complaint for Declaratory, Injunctive, or Other Relief and for Review of Agency Action, Gill v. U.S. Postal Serv., No. 1:09-cv-10309 (Mass. Dist. Ct. Mar. 3, 2009), available at http:/www.glad.org/uploads/docs/cases/gill-complaint-03-03-09.pdf.

236. GLAD's amended complaint does not include allegations regarding the passport.

237. See Emens, supra note 96, at 789 (finding that seven percent of women shared names, rather than four percent of men; drawing no distinction between taking one partner's name over the other and creating a new last name).

238. Victoria Clarke, Maree Burns \& Carole Burgoyne, Who Would Take Whose Name? Accounts of Naming Practices in Same-Sex Relationships, 18 J. COMMUNITY APPLIED SOC. PSYCHOL. 420, 427-28 (2008) (reporting that one of the sixteen couples interviewed reported sharing a last name with the remaining participants either saying no to name change or indicating no decision on name change or that name change was a future possibility).

239. Id. at 433 . 
opportunity to reevaluate this practice in light of its gendered heritage. To the extent that marital name change is currently gendered, same-sex marital naming presents the possibility of disrupting the assumption that men keep and women change. This reconsideration has broader implications. It opens the way toward examining in greater detail the ways in which marriage is still deeply gendered, despite formal equality, and suggests the ways in which seemingly trivial practices, like marital naming, participate in that gendering.

Thorough reconsideration of traditional marital naming and traditional ways of naming marriage offers an opportunity to reformulate marriage toward a more egalitarian norm for the straights and gays who seek to marry. Greater attention to the gendered aspects of these areas of naming, arising both at the outer boundary of and within marriage, paves the way toward destabilizing some of the gender hierarchy of the marital institution.

\section{CONCLUSION}

The seeming triviality of language makes it easy for family law scholarship to overlook the substantive implications of terminology. But the risks of overlooking the relationship between language and status include the unwitting perpetuation of social hierarchies within family law. Because language seems trivial, language practices can operate undetected to reflect and reinforce hierarchical relationships. As I have discussed, naming marriage and marital naming demonstrate these dynamics.

As this analysis has shown, language constitutes status in a "public" sense, as when the state is the speaker, as well in a "private" sense, when individuals pursue language practices. To the extent that some language practices, like marital names, operate against the formal neutrality of the law, what lessons can we glean from a statusfocused analysis of such practices? The continuation of social practices that mimic a legally set status quo carries implications for the law insofar as these practices force consideration of residual biases in the law as well as of the ways in which social practices themselves act as constraints in much the same fashion as formal law.

While the status effects of language in the same-sex marriage context suggest a clear legal outcome (the state conferring the title "marriage" to same-sex couples), this Article does not advocate for a discrete legal fix for the gender hierarchy in marital names. The sparse contemporary literature on marital names has included proposed legal solutions for the "stickiness" of name-change norms, most notably those advanced by Elizabeth Emens. ${ }^{240}$ Emens's suggestions include more thoughtful consideration of the ways in which the state asks parties about name changing, the context surrounding those questions, and the information supplied with those questions. $^{241}$

While I agree with Emens that the legal "framing" of questions and options concerning marital names is a serious and important opportunity for altering conduct, ${ }^{242}$ I am less optimistic about the ultimate social impact that such changes, many of which would occur on administrative forms, can effect on the ability of

240. See Emens, supra note 96 , at $813,839-61$.

241. Id. at 839-54.

242. See id. at 839 . 
women and men to make their name choices more freely. In marital names, formal law has failed to deliver substantively on its promise of equality. The solution to formal law's failure in the names context would not seem to lie in more law, but rather in a reconsideration of norms.

Strict prohibition of marital name change provides another possibility for reform. In Quebec, women are prevented from taking their husbands' name at marriage. The Quebec Civil Code states, "In marriage, both spouses retain their respective names, and exercise their respective civil rights under those names." ${ }^{243}$ Canadian citizens who are residents in Quebec may change their name only after overcoming additional administrative hurdles. In order to successfully change their name, they must receive authorization from the registrar of civil status, who may "authorize a change of name for a serious reason." 244

While such a prohibition may hold some appeal from an expressive standpoint, insofar as it demonstrates an egalitarian approach that our current system aspires to, I have concerns about the backlash against such an approach. Indeed, some Quebecois women today, twenty years after the law went into effect, are questioning this restriction on their naming choices. ${ }^{245}$

Moreover, without a broader shift in gender norms in marriage and the family, a strict legal prohibition of name change would merely amplify the sense that marital name change is about women's choice (or the denial of that choice), while leaving fully intact the prevailing gender-based construction of name change.

A broader reconsideration of marital-name norms involves looking at names as a social practice integrally tied to other areas of the law that we collectively take for granted as affecting status. By recognizing these connections, we can better appreciate the stakes in practices as seemingly trivial as names. I hope to prompt more serious consideration of marital names in the realm of social practice, with the hope that such intervention might shift norms in ways that the law has failed.

Distinctions between language practices based on public and private action are less important when we take into account problems with choice in the so-called private sphere. Problems of choice regarding names arise partly because name decisions occur in the midst of social forces that dictate our background sense of women's freedom, in the context of names and beyond. Name practices, accordingly, reflect the hierarchy that both limits that freedom and reinforces it. But because names are deeply intertwined with gender hierarchy, the solution to the problem with names lies in a more fundamental improvement in women's status, in addition to specific reconsideration of marital-naming practices. This broader cultural shift is beyond the scope of this Article, but I do hope to start a conversation about how women's names relate to far-reaching discussions about women's substantive freedom to govern their lives both within and at the intersections of sexuality, family, and the workplace.

243. R.S.Q., ch. 64, art. 393 (1991), available at http://www.canlii.org/qc/laws/sta/ccq/ 20080818/whole.html.

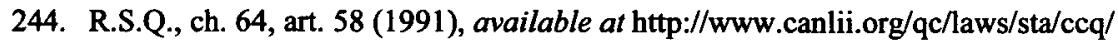
20080818/whole.html.

245. See Marion Scott, Married Name Dilemma: His or Hers?, GAZETTE.COM (Montreal), Nov. 30, 2007, http://www2.canada.com/montrealgazette/news/arts/story.html?id=50d1923108be-4717-acf3-50e4ece27ae2. 
My more modest aim in this Article has been to identify naming more explicitly as a status issue and to provide a detailed account of the intersection between language and status in family law. The examination of language and status in this Article can inform our understanding of the power dynamics at play in other areas of family law predicated on struggles over categories. For example, assisted reproductive technology has brought to the fore questions about who is a "mother" and who qualifies as a "parent." 246 An examination of the status-constituting effects of language in the assisted reproductive context would enable deeper consideration of the ways in which language practices and construction of the terms "mother" and "parent" reinforce hierarchies between straights and gays, married women and single women, and women and men. Such an analysis would enhance our understanding of how language bears on status by reflecting and reinforcing social hierarchy within family law institutions and more broadly.

246. See, e.g., K.M. v. E.G., 117 P.3d 673, 682 (Cal. 2005) (holding that an egg donor and her former same-sex partner, the gestational mother, were both mothers of the resulting child); Johnson v. Calvert, 851 P.2d 776, 782 (Cal. 1993) (holding that the genetic parents of a child gestated through a surrogate were the "natural parents"). 


\section{HISTORICAL APPENDIX ON FEMINISM AND NAMES}

Debates about married women's names played an important role in challenges to the status of women in nineteenth- and twentieth-century feminism. This Appendix highlights the significance of naming to broader feminist movements and the view of women's names as indicative of women's public status.

\section{A. Names and Feminism's First Wave}

The custom and law of marital name change came to signify, for prominent feminists of the day, the mandated loss of women's individuality and the state-enforced subordination of women in marriage. While suffrage became a central issue for early feminists, equality within marriage was also an important question of the day. Women's names emerged in the early feminist movement as a means to establish public recognition of women's equality.

While early feminists did not necessarily always agree on the methods of advancing women's interests, ${ }^{247}$ the goal of women's self-determination was fundamental to the early feminist agenda. ${ }^{248}$ One area in which the issue of self-determination was particularly salient was marriage. American feminists took the question of marriage reform seriously, ${ }^{249}$ for some, marriage reform was even more important than

247. Tensions arose among early feminists over the relative importance of suffrage compared to issues like the status of women in marriage. For example, at the 1860 Women's Rights Convention, some participants aimed to bar the marriage issue from discussion and wanted instead to focus on more practical concerns like suffrage. Debates on Marriage \& Divorce, Tenth National Women's Rights Convention (May 10, 1860), reprinted in THE CONCISE HISTORY OF WoMAN SUFFrage 170, 186-87 (Mari Jo Buhle \& Paul Buhle eds., 1978).

248. While suffrage was a key concern, the "first wave" of feminism, roughly spanning three generations from the 1850 s until women gained the right to vote in 1920 , also addressed issues such as education, professional careers, culture, married women's economic and legal dependence, sexual and moral double standards, women's control over their bodies, the hardships of housework, low wages, and women's exclusion from politics. MARLENE LEGATES, IN THEIR TIME: A HISTORY OF FEMINISM IN WESTERN SOCIETY 197 (2001). A principal concern underlying these issues was the ability of women to "define their own capabilities and goals." Id.

The resolution drafted by the participants of the 1851 Women's Rights Convention articulated this goal particularly well:

Resolved, That we deny the right of any portion of the species to decide for another portion, or of any individual to decide for another individual what is and what is not their "proper sphere"; that the proper sphere for all human beings is the largest and highest to which they are able to attain; what this is, can not be ascertained without complete liberty of choice; woman, therefore, ought to choose for herself what sphere she will fill, what education she will seek, and what employment she will follow, and not be held bound to accept, in submission, the rights, the education, and the sphere which man thinks proper to allow her.

Second National Convention Resolutions (Oct. 15-16, 1851), reprinted in THE CONCISE HISTORY OF WOMAN SUFFRAGE, supra note 247, at 112-13.

249. See Joelle Million, Woman's Voice, Woman's Place 2 (2003) (discussing how 
suffrage. ${ }^{250}$ At early women's rights conventions, participants spoke more often of "resentment at wives' subordination within marriage" than even of suffrage. ${ }^{251}$ The marriage-reform agenda included property reform, child custody, guardianship rights for mothers, and equality in divorce. ${ }^{252}$

For early feminists, the preservation of women's individual identity and selfhood animated their objections to the treatment of women in marriage. For example, Ernestine Rose, a contemporary of Stone and Stanton, described the problem with marriage in identity terms: "[L]et us first obtain ourselves. Give us ourselves and all that belongs to us will follow."253

The problem of women's identity in marriage played out dramatically in the legal and social assumption that a woman would take her husband's last name. The law and practice of marital name change symbolized for many the subordinate status of women in marriage.

This was certainly true for abolitionist and women's rights activist Lucy Stone and her husband, the abolitionist Henry Blackwell. When the two married in 1855, they agreed that Lucy Stone would not take Henry Blackwell's name. Wrote Stone to Blackwell, "A wife should no more take her husband's name than he should hers. My name is my identity and must not be lost."254

And Blackwell, in agreement, wrote back, "I wish, as a husband, to renounce all the privileges which the law confers upon me, which are not strictly mutual. Surely such a marriage will not degrade you, dearest.",255 At their marriage ceremony, the two denounced "the present laws of marriage, as [the laws] refuse to recognize the wife as an independent, rational being, while they confer upon the husband an injurious and unnatural superiority, investing him with legal powers which no honorable man would exercise, and which no man should possess."256

many women saw reformation of marriage as a major priority for the early women's movement).

250. See CoTT, supra note 12, at 64.

251. Id. For example, one commentator wrote in 1870 in the newspaper nun by Elizabeth Cady Stanton and Susan B. Anthony:

The ballot is not even half the loaf; it is only a crust-a crumb. The ballot touches only those interests, either of women or men, which take their root in political questions. But woman's chief discontent is not with her political, but with her social, and particularly her marital bondage. The solemn and profound question of marriage . . . is of more vital consequence . . . than any such superficial and fragmentary question as women's suffrage.

LeGates, supra note 248, at 208 (quoting William L. O'Neill, FEMINISM IN

AMERICA: A HISTORY 19-20 (2d ed. 1989)) (alteration in original).

252. See LEGATES, supra note 248 , at 209 (stating that feminists disagreed about divorce due to the adverse economic consequences for women of divorce).

253. Françoise Basch, Woman's Rights and the Wrongs of Marriage in Mid-NineteenthCentury America, 22 HIST. WORKSHOP J., Autumn, 1986, at 18, 22 (quoting Emestine Rose, Address at the Seventh National Convention of Women's Rights, in ProceEdiNGS OF THE SEVEnth National Convention of Women's Rights, New York, 1853, at 41 (1856)) (emphasis in original).

254. ASHLYN K. KuERSTEN, WOMEN AND THE LAW: LeAdERS, CASES, AND DOCUMENTS 19 (2003).

255. Id.

256. Henry Blackwell \& Lucy Stone, Protest, reprinted in THE CONCISE HISTORY OF WOMAN SUFFRAGE, supra note 247, at 151, 151. Stone, who began lecturing in women's rights 
Lucy Stone's concern over marital names comported with the concerns of the first wave of feminist activists over the status of women in the family. ${ }^{257}$ She counted among her feminist friends Elizabeth Cady Stanton and Susan B. Anthony. ${ }^{258}$ Cady Stanton, in particular, supported Stone's decision to discontinue using her husband's last name, responding:

Nothing has been done in the woman's rights movement for some time that so rejoiced my heart as the announcement by you of a woman's right to her name... . [I]t does seem to me a proper self-respect demands that every woman may have some name by which she may be known from the cradle to the grave. ${ }^{259}$

In contrast to Lucy Stone, however, many nineteenth-century feminists who were concerned with naming focused on establishing the right of women to use their given first names - to be called, for example, Mrs. Harriet Smith, rather than Mrs. John Smith. ${ }^{260}$ The feminists at the 1848 Women's Rights Convention in Seneca Falls, New York, used their own first names, rather than those of their husbands, when addressing each other and signing the Declaration of Sentiments. ${ }^{261}$ Elizabeth Cady Stanton informed friends when she married in 1840 that they were to call her Elizabeth Cady Stanton, rather than Mrs. Henry B. Stanton. ${ }^{262}$

in 1847 after graduating from Oberlin College, saw in the custom of women changing their names the erasure of women's individual identity. See STANNARD, supra note 101, at 95. As described by Una Stannard, by fourteen months after her marriage to Henry Blackwell, Lucy Stone began consistently to be known as Lucy Stone, rather than Lucy Blackwell or Lucy Stone Blackwell. Id. at 96-97. In 1856, she asked that Susan B. Anthony refer to her as Lucy Stone in that year's women's rights convention call. Id. at 97 . She was reported to have told her friends, "a wife should no more take her husband's name than he should take hers." Id. at 98 . Up until that point, Lucy Stone had apparently allowed her friends, colleagues, and husband to attach "Blackwell" to her name. Id. at 97-98. For the remainder of her life, Lucy Stone referred to herself as and signed her name "Lucy Stone." Id. at 98. On occasion, however, she added "wife of Henry Blackwell" to her signature on legal documents because lawyers and bureaucrats would often refuse to accept her signature without her husband's last name. Id. at 102. Lucy Stone has been credited with being the first nineteenth-century American woman to retain her surname after marriage, but she may have been preceded by a New York doctor by the name of Mary E. Walker, who was married in 1855-the same year Lucy Stone married Henry Blackwell. Id. at 132-33. While Walker continued to use her surname after the marriage, Stone did not finally repudiate her husband's last name until 1856. Id. at 133. Moreover, Stone and Blackwell openly flouted tradition for thirty-seven years, while Walker was divorced in 1859 and arguably made less of an impact than Stone. Id. at 132-33. Other, lesser-known women of the nineteenth century retained their surnames upon marriage, as eloquently described by Una Stannard. Id. at $132-50$.

257. See Declaration of Sentiments and Resolutions, Seneca Falls Convention of 1848, reprinted in THE CONCISE HISTORY OF WOMAN SUFFRAGE, supra note 247, at 94 ("He has made her, if married, in the eye of the law, civilly dead. He has taken from her all right in property, even to the wages she earns.").

258. See STANNARD, supra note 101 , at 98.

259. Id.

260. Id. at 4.

261. Id. at 3 .

262. Id. 
Although winning the right to vote eventually took precedence in the years leading up the passage of the Nineteenth Amendment, women's name rights occupied a surprisingly high profile place in the pantheon of issues feminists discussed. For example, the National Women's Party, known for its aggressive tactics to win support for women's suffrage, took up the cause of women's name rights in the years before women won the right to vote. ${ }^{263}$

Changes in marriage laws, removing some of the legal impediments facing married women, gave reason to reconsider marital-name practices. The Married Women's Property Acts, first appearing in 1835 in Arkansas ${ }^{264}$ and spreading to other states throughout the late $1830 \mathrm{~s}$ and $1840 \mathrm{~s},{ }^{265}$ gave married women the legal power to hold property and sue and be sued as "femme sole," in their own names, rather than through their husbands. ${ }^{266}$ This legislative change mitigated some of the effects of marriageinduced "civil death" that women experienced. ${ }^{267}$ Because married women were now

263. The CONCISE History OF Woman SUffrage, supra note 247, at 427. The National Woman's Party (NWP) was first organized in 1913 under the name of the Congressional Union for Woman's Suffrage. Id. This was an offshoot of the National American Woman Suffrage Association (NAWSA) headed by woman's rights leaders Alice Paul and Lucy Burns. Id. Paul and Burns were considered radicals and broke from the NAWSA leadership when the group evolved into the Woman's Party in 1916, and finally the NWP in 1917. See Nancy F. Cott, Feminist Politics in the 1920s: The National Woman's Party, 71 J. AM. Hist. 43, 44 (1984). Unlike other suffrage organizations, the NWP was more political than educational. Id. at 44. It concentrated on gaining voting rights for women at the federal rather than the state level by advocating for an amendment to the Constitution. See id. at 45. From marches and songs to pickets and arrests, the headline-grabbing tactics of the NWP created support for suffrage throughout the country. See LINDA J. LuMSDEN, RAMPANT WOMEN: SUFFRAGISTS AND THE RIGHT OF ASSEMBLY 129 (1997). After the passage of the Nineteenth Amendment, Paul reorganized the NWP in 1922 with the broader goal of ending all discrimination against women. Cott, supra at 48.

The NWP represented Dr. Marjorie Jarvis, a government-employed physician in Washington, D.C., who sought to receive her paychecks in her own name, rather than her husband's. Feminists Deny that Wife Must Bear Husband's Name, N.Y. TIMES, Sept. 28, 1924, at X12. In addition, they represented Ruby Black, a newspaper reporter who sought to obtain a passport in her own name, and eventually won this right after an appeal to the Secretary of State Frank Billings Kellogg. STANNARD, supra note 101, at 206.

264. Richard H. Chused, Married Women's Property Law: 1800-1850, 71 Geo. L.J. 1359, 1398-99 (1983) (citing Act of Nov. 2, 1835, Ark. Terr. Laws 34-35 (1835)).

265. See id. at 1399-1400.

266. E.g., ARK. CODE ANN. § 9-11-502 (2008) ("Every married woman ... shall have all rights to contract and be contracted with, to sue and be sued ... a though she were a femme sole."); DEL. CODE ANN. tit. 25, § 173 (1989) ("A married woman may make a letter of attorney the same as though she were a feme [sic] sole."); Mo. REV. STAT. $\S 442.030$ (2000) ("And any covenant expressed or implied in any deed conveying property belonging to the wife shall bind the wife and her heir to the same extent as if such wife was a femme sole.").

267. Blackstone's idea of "unity of person" supposedly made families stronger, yet members of the feminist movement saw this "civil death" as an opportunity to create change. They fought for reforms to eradicate married women's subordination to their husbands. Beginning in the 1830s, Married Women's Property Acts gave women the power to control and dispose of their own property. In turn, increased control over property gave women more power within marriage. See Norma Basch, Invisible Women: The Legal Fiction of Marital Unity in 
able to make contracts, feminists like Elizabeth Cady Stanton suggested that women not change their names, to avoid the confusion that could arise from such changes. ${ }^{268}$

Legal reforms like the married women's property acts, however, did not dislodge the doctrine of marital unity, which served as justification for the name-change practice. For example, when government-employed Dr. Marjorie Jarvis sought to receive her paycheck with her maiden name, rather than her married name, her case came to the attention of the Secretary of the Interior, who referred it to the Controller General for a ruling. ${ }^{269}$ Although the Married Women's Property Act recognized the wife as "femme sole," capable of suing and being sued, the legislation left intact "the old rule of married unity."270 To the Controller General, that meant that the increased autonomy of married women did not render them separate legal entities. He stated:

Each family is a unit in the body politic, and it can hardly be imagined of husbands, wives and children composing the same family bearing different names.

... The separate legal entity of the wife is not so generally recognized as to accept the maiden name rather than the surname of the husband. 271

At stake in the early feminist critique of name-change law was the public recognition, through the law, that women were equal, autonomous individuals. The preservation of individual identity through name keeping was one route to this recognition of equality. Lucy Stone couched her objections to name change precisely in terms of loss of identity for women: "My name is the symbol of my identity which must not be lost." 272

Feminist arguments for women's control over their names focused on the absence of legitimate legal mandate requiring name change. In Dr. Jarvis's case, the National Women's Party, along with the Women's Bar Association and the Lucy Stone League, ${ }^{273}$ reportedly took the position that

Nineteenth-Century America, 5 FEMINIST STUD. 346, 355 (1979).

268. STANNARD, supra note 101, at 98.

269. Feminists Deny that Wife Must Bear Husband's Name, supra note 263.

270. Id.

271. Id.

272. STANNARD, supra note 101, at 192.

273. The Lucy Stone League is an organization that advocates for name-change equality for both women and men "in all aspects and venues of personal and civil life." Lucy Stone League, $\mathrm{http} / / \mathrm{www}$.lucystoneleague.org/lucy.html. Named after Lucy Stone, the League was created in 1921 to enable women to retain their maiden names after marriage. Maiden Namers Score a Victory, N.Y. TIMES, May 15, 1921, at 9. The group originally decided that the aim of the organization should primarily be education, rather than formal lobbying for changes in the law. Wives Debate Right to Maiden Names, N.Y. TIMEs, May 18, 1921, at 27. The group quickly deviated from this intent by getting involved in a host of issues pertaining to the right of married women to use their birth names in various capacities. The group embarked on campaigns "to obtain passports, register at hotels, check books out from a library, receive paychecks, and obtain copyrights using their birth name." Roxanne Friedenfels, The Lucy Stone League: The Three Historical Periods, http://www.lucystoneleague.org/history.html. The League asserted that women were legally entitled to each of these actions, and "that it was only custom that kept 
[n]o woman who enters into the marriage contract forfeits the name by which for two or more decades she has been known... There is nothing in the statute books that proves that she must abandon it, any more than when two men enter into a business relationship one of them must give up his name and become known by that of his associate. ${ }^{274}$

For those who objected to mandated name change, the practice represented, fundamentally, the subjugation of wives to male authority and a denial of women's

women from doing them without a problem." Id. By the end of the 1920s, the Lucy Stone League had become inactive and "it was believed that there was no longer any question about the legal and social right to use a pre-marriage name." Id.

The League was reconstituted in 1950 by one of its original founders, journalist Jane Grant. Susan Henry, "We Must Not Forget We Are Dealing with a Woman": Jane Grant's Return to a Magazine and a Cause, 33 JOURNALISM HIST. 151, 156 (2007). This new League focused more broadly on women's status in society and fighting against sex discrimination generally. Id. Through the late 1990s, the Lucy Stone League continued to advocate for women's rights, though most of their causes were taken up more effectively by the National Organization for Women (NOW). Friedenfels, supra. The League relegated itself to giving out scholarships and holding annual meetings. Id.

In 1997, the League was revitalized into the current incarnation that exists today-a refocused organization dedicated primarily to name equality. Id. With organizations like NOW focusing on the wide array of women's issues, current president Morrison Bonpasse saw a vacuum on the name equality front and has focused the League exclusively on name issues. Id. The League attempts to serve an educational function, advocating directly to people about the rights of name change equality through speaking engagements. See Lucy Stone League: Latest News, http://www.lucystoneleague.org (follow "latest news" hyperlink). The League engages in more modern publicizing through the social networking webpage, Facebook.com. Facebook, The Lucy Stone League, http://www.facebook.com/group.php?gid=2216878731. The League's website declares one of their priorities to be the "No More Maidens" campaign, an effort by the organization to abolish "the anachronistic practice of using maiden names as security passwords." Lucy Stone League, http://www.lucystoneleague.org/oldnews.html.

274. Feminists Deny that Wife Must Bear Husband's Name, supra note 263. Of the Jarvis case, Alice Paul, Vice President of the National Women's Party, asked,

Why should a woman renounce the name under which she has been for many years established? Professionally it is injurious to her career, legally it is unjust. It is an unfair discrimination against sex. There is no law that forbids a woman to continue the use of her maiden name. She has the same right a man has to retain the name given her at birth, whether she is single or married.

Id. Lucy Stone contended, "It is a mistaken idea that woman is obliged to give up her name and take that of her husband, by the ceremony. I have not given up mine, and no law can compel me to. I call myself Lucy Stone, and shall always." STANNARD, supra note 101, at 103. Rose Fall Bres, President of the National Women Lawyers Association in 1924 and attorney for the Lucy Stone League, also argued regarding Dr. Jarvis's case, "I know of no written law that upholds [the Comptroller General's decision against Dr. Jarvis]." Feminists Deny that Wife Must Bear Husband's Name, supra note 263.

In arguing in favor of women's name retention rights, one female attorney in New York, Lucille Pugh, when asked about whether women were required by law to change their names upon marriage, drew a distinction between law and custom when she maintained that "while it is a universal custom for a woman to take her husband's surname, she had a right to retain her maiden name or to assume a different name if she chose." Married Woman Can Use Birth Name, N.Y. Times, Jan. 17, 1915, at C4 (emphasis added). 
autonomy. Timothy Walker, an Ohio attorney, wrote in his treatise Introduction to American Law, ${ }^{275}$ published in 1837, that a wife's loss of her name in marriage showed the "slavish subjection of wife to the husband." ${ }^{276} \mathrm{He}$ continued, " $[\mathrm{t}]$ he merging of her name in that of her husband, is emblematic of the fate of all her legal rights. The torch of Hymen serves but to light the pile, on which these rights are offered up." ${ }^{277}$ Walker objected to marriage law, as it existed at the time, calling it "a disgrace to any civilized nation." 278

In sum, the struggle over women's names during the first wave of feminism was, in effect, a struggle to gain public respect for women's autonomy and worth, relative to men. While the subject of women's names would give way to suffrage for some of name rights' staunchest champions - like Lucy Stone ${ }^{279}$ — the issue persisted to varying degrees of intensity for others up until and after women won the right to vote with the passage of the Nineteenth Amendment in 1920.

As late as 1924, the novelist Fannie Hurst, who, like other female authors, continued to publish under her birth name after marriage, raised the issue of women's names. Hurst decried the status quo of name change, saying of her fellow women, "[w]hat I most deplore is the attitude of the women at large, their apathy, their willingness to draw themselves back into the circle of the good old-fashioned wife and mother. They take the course of least resistance. They are simply clinging to another man-made idea." 280

\section{B. Names and Feminism's Second Wave}

Names endured as a vehicle for securing public recognition of women's equality during what is often called the "second wave" of feminism, stretching from the 1960s until the 1990 s. $^{281}$ By the 1960 s and early 1970 s, "many women began consciously

275. TIMOTHY WALKER, INTRODUCTION TO AMERICAN LAW: DESIGNED AS A FIRST BOOK FOR StUdENTS (Philadelphia, P.H. Nicklin \& T. Johnson 1837); STANNARD, supra note 101, at 94 (discussing Walker's views).

276. WALKER, supra note 275 , at 651 .

277. Id. at 223.

278. Id. at 222.

279. After the mid-1800s, Lucy Stone became more reticent on the subject of women's names, declining to write about women's name rights in The Woman's Journal, the feminist newspaper she edited with her husband Henry Blackwell. STANNARD, supra note 101, at 105. Una Stannard suggests it is because Stone was prioritizing suffrage over women's names. Id.

280. Feminists Deny that Wife Must Bear Husband's Name, supra note 263. At the time, actresses and authors were the two groups of women who fairly consistently kept their own names, at least professionally, after marriage. SUSAN J. KUPPER, SURNAMES FOR WOMEN: A DECISION-MAKING GUIDE 13 (1990).

281. See Steven M. Buechler, Women's Movements IN the Untted States: Woman SUFFRAGE, EQUAL RIGHTS, AND BEYOND 3 (1990). While the characterization of American feminism as emerging in "waves" has been criticized, e.g., id. at 3; Dawn Keetly \& John Pettegrew, Liberal Feminism, Women's Liberation, and the Emergence of Radical Feminism, in Public Women, Public Words 3 (Dawn Keetley \& John Pettegrew eds., 2005), I rely on this approach because it is useful for thinking about the bursts of discussion pertaining to women's names. 
seeking ways to retain their maiden names."282 Indeed, social scientists have documented dramatic increases in name retention after the $1960 \mathrm{~s}^{283}$ This Part recounts briefly the history and themes surrounding name-rights activism during the second wave of feminism. I argue that disputes over the names women bore-or could choose to bear-reflected a broader struggle, akin to that of the late nineteenth and early twentieth centuries, about women's subordinate position in society.

While some have credited the increased workforce presence of women for the interest in name keeping, ${ }^{284}$ Susan Kupper found, in her study on women's name practices, a broader connection between the 1970s women's movement and name keeping. Based on interviews with women discussing their name practices, she found that women who grew up in the late 1960s and 1970s were influenced by the feminist movement and viewed retaining their names as a means of asserting their independence. ${ }^{285}$ " $[\mathrm{M}]$ any well-educated women who grew up in the late 1960 s and the 1970 s have carried the ideas from the women's movement into their own relationships. They felt they had to assert their autonomy vis-à-vis men and not become subjugated." ${ }^{286}$ Based on this view, name practices implicated women's autonomy and freedom from patriarchy.

The autonomy these women sought involved, in part, the ability to define one's own identity. As in the first wave of feminism, the ability of women to control their names signified the opportunity to define their own identities. At stake in the right to one's name was "the psychology of being yourself instead of living through someone else.,287

Retaining one's name also represented the potential for equality in marriage, ${ }^{288}$ as it did for early feminists. ${ }^{289}$ Although major goals of the second wave were employmentdiscrimination legislation, the proposed Equal Rights Amendment, and sexdiscrimination litigation, ${ }^{290}$ equality within marriage - as during the first wave of

282. Omi Morgenstern Leissner, The Name of the Maiden, 12 WIS. WOMEN's L.J. 253, 257 (1997).

283. According to a 2000 study by Laurie K. Scheuble, Katherine Klingermann, and David R. Johnson, there was a dramatic increase in the prevalence of women choosing nonconventional names (hyphenating or keeping name) between 1966 and 1996. Scheuble et al., supra note 81, at 107-09 (surveying 2163 wedding announcements in the New York Times over thirty years). Between 1990 and 1996, women were almost twenty-seven times more likely to take a nonconventional name than women married from 1966 to 1971 . The percentage of U.S. college-graduate women who kept their surnames upon marriage rose from about two to four percent around 1975 to just under twenty percent in 2001. Goldin \& Shim, supra note 4, at 148.

284. See Leissner, supra note 282 , at 257 (positing that as women increasingly established themselves professionally prior to marriage, they sought to retain the reputations they had built by keeping their names when they married).

285. KUPPER, supra note 280, at 133; see also MacDougall, supra note 102, at 93 (characterizing the right of women to choose their surnames as a "feminist" issue).

286. KUPPER, supra note 280 , at 133.

287. The Name Game, TIME, May 13, 1974, at 95 , available at http://www.time.com/time/magazine/article/0,9171,908591,00.html (quoting Pat Montandon, a San Francisco writer and former television moderator).

288. See Leissner, supra note 282, at 257.

289. See supra text accompanying notes 251-56.

290. Leissner, supra note 282, at 257. 
feminism-was an area of significant concern. ${ }^{291}$ To many second wave feminists, according to Omi Morgenstern Leissner, the practice of name change looked like an "agent for preserving the present social structure."

The 1970s was also a fertile time for activism around the issue of women's names. This era witnessed a surge in activism to educate and lobby for the rights of women to control their names. The Center for a Woman's Own Name was organized in 1973 and worked with the American Civil Liberties Union to advocate for the recognition of women's rights over their names and those of their children. ${ }^{293}$ These efforts resulted in guides on naming like Booklet for Women Who Wish to Determine Their Own Names After Marriage, ${ }^{294}$ published in $1974 .^{295}$

That same year, the Olympia Brown League was founded to aid women in Milwaukee, in response to a trial court decision restricting women's name rights. ${ }^{296}$ Massachusetts women founded Name-Change in 1972, after the Alabama district court decision in Forbush v. Wallace, ${ }^{297}$ also restricting women's right to retain their surnames upon marriage. ${ }^{298}$ The group disseminated materials with information for women who sought to retain their surname after marriage and advocated for women's right to control their names. ${ }^{299}$ Women in Michigan and California also organized to educate the public and promote name rights for women. ${ }^{300}$ The Women's Legal Defense Fund in Washington, D.C. also published a booklet on women's names for residents of Washington, D.C. ${ }^{301}$

Litigation served as another form of activism on the name issue. Women's organizations, law students, and legal services organizations joined the debate about marital names by participating in the litigation on the subject brewing in the courts in the 1970s. ${ }^{302}$ For example, the NOW Legal Defense and Education Fund participated in Kruzel v. Podell ${ }^{303}$ as amicus curiae. ${ }^{304}$ NOW and the National Conference on Women and the Law also set up task forces and workshops on the naming issue. ${ }^{305}$

291. Id.; see, e.g., BETTY FRIEDAN, ThE FEMININE MySTIQUE (1963) (describing the dissatisfaction of housewives with the traditional division of labor between husbands and wives as "the problem that has no name").

292. Leissner, supra note 282, at 257.

293. MacDougall, supra note 102, at 94 n.5.

294. CTR. FOR A WOMAN'S OWN NAME, BOOKLET FOR WOMEN WHO WiSh TO DETERMINE THEIR OWN NAMES AFTER MARRIAGE (1 st ed. 1974).

295. Id.

296. See Kruzel v. Podell, 226 N.W.2d 458, 460 (Wis. 1975) (reasoning that since state statute allowed women to resume their maiden names upon divorce, the trial judge assumed that the statute also indicated that a woman must take her husband's surname at marriage). According to Priscilla MacDougall, the League took its name from the country's first female ordained minister, from Wisconsin, who kept her own name when she married in 1873 . MacDougall, supra note 102 , at 94 n.5.

297. 341 F. Supp. 217 (M.D. Ala. 1971), aff'd without op., 405 U.S. 1197 (1972) (per curiam).

298. See MacDougall, supra note 102, at 94 n.5 (citing Forbush, 341 F. Supp. at 217).

299. MacDougall, supra note 102, at 94 n.5.

300. Id.

301. Id.

302. See id.

303. 226 N.W.2d 458 (Wisc. 1975). 
At issue for these organizations was a woman's choice to determine her name. For example, the Center for a Woman's Own Name did not mandate a particular outcome for women's names, but concerned themselves with protecting a woman's right to the name of her choice, whether that be "the name given her at birth, a name assumed during childhood, assumed at marriage, assumed at a previous marriage, a hyphenated name or a name made up by herself at any time."306

The effects of second wave feminists led directly to the legal shift creating formal equality in which marital naming operates today. While this formal change has only enjoyed partial success, the efforts of first and second wave feminists were instrumental in highlighting the public stakes at issue in marital naming.

304. Brief of American Civil Liberties Union and National Organization for Women, Legal Defense and Education Fund as Amici Curiae Supporting Petitioner, Kruzel v. Podell, 226 N.W. 2d 458 (Wis. 1975) (No. 367).

305. MacDougall, supra note 102, at 94 n.5.

306. MacDougall, supra note 102, at 94 n.5 (quoting CTR. FOR A WOMAN's OWN NAME, 1975 SUPPLEMENT TO BOOKLET FOR WOMEN WHO WISH TO DETERMINE THEIR OWN NAMES AFTER MARRIAGE 6 (1975)). 
